\title{
NUEVA LECTURA DE NIEBLA: KIERKEGAARD Y EL AMOR
}

\author{
J. A. G. ARDILA \\ University of Edinburgh
}

\section{RESUMEN}

Las interpretaciones críticas de Niebla han inspeccionado diversas capas de significación en la mucha hondura de esta novela. Los estudios dedicados a conmensurar la presencia de la obra de Kierkegaard en Niebla han tratado cuestiones de estructura narratológica además de coincidencias (que no influencias) circunstanciales. En el presente trabajo se cuantifica el influjo del Diario del seductor de Kierkegaard antes de abordar la influencia de esta novela así en Del sentimiento trágico de la vida como en Niebla. Tanto en Niebla como en el Diario del seductor sus autores presentan la tesis de que el auténtico sentido de la vida reside en el amor verdadero o espiritual. La deuda de Unamuno con Kierkegaard obliga a reconocer en el Diario del seductor la principal fuente literaria y filosófica de Niebla.

Palabras clave: Unamuno, Niebla, Kierkegaard, existencialismo.

\section{NEW READING OF NIEBLA: KIERKEGAARD AND LOVE}

\begin{abstract}
Unamuno's Niebla [translated into English as Mist] has been the object of many critical interpretations. Few critics have linked Mist to Kierkegaard, contending that the narrative plot of Mist was mainly influenced by Kierkegaard, and randomly pointing out coincidences between Unamuno's novel and Kierkegaard's works. This article quantifies the influence of Kierkegaard's Diary of a Seducer on Mist and concludes that Kierkegaard's novel has strong bearing on Unamuno's The Tragic Sense of Life and Mist. The main thesis posited by Unamunuo in Niebla is here identified and found to be inspired by Kierkegaard's Diary of $a$ seducer: spiritual love is the true sense of life. Kierkegaard's Diary must be regarded as the literary and philosophical source of Mist.
\end{abstract}

Key words: Unamuno, Mist, Kierkegaard, Existentialism.

\section{INTRODUCCIÓN}

Con relativa asiduidad se ha entroncado la obra y el pensamiento de Miguel Unamuno con la filosofía de Søren Kierkegaard, hasta el punto de 
haberse calificado al danés de «su hermano espiritual» ${ }^{1} \mathrm{y}$ «his intellectual soulmate ${ }^{2}$. No escasean los opúsculos publicados en este respecto, v.g.: Gemma Roberts ${ }^{3}$ apuntó toda suerte de coincidencias entre Kierkegaard y las novelas Niebla y Abel Sánchez; Jesús Collado se ocupó de entender «lo religioso-existencial» ${ }^{4}$ del danés en el escritor bilbaíno; Antonio SanchezBarbudo $^{5}$ señaló en Kierkegaard, aunque con reservas, el germen intelectual de la angustia que produjo a Unamuno su archiconocida crisis de 1897; Adolfo Carpio ${ }^{6}$ sistematizó las aparentes contradicciones unamunianas en función del pensamiento kierkegaardiano, y yo mismo ${ }^{7}$ traté de explicar (como mejor pude) el discurrir político de Unamuno en función del método dialéctico de Kierkegaard. Los más de estos estudios se centran en la obra filosófica de Unamuno ${ }^{8}$, especialmente en Del sentimiento trágico de la vida, y pocos han ahondado en sus obras de ficción ${ }^{9}$. Acerca de Niebla escribió

${ }^{1}$ RoBERTS, Gemma, Unamuno: afinidades y coincidencias kierkegaardianas, Boulder, Society of Spanish and Spanish-American Studies, 1986, 55.

2 SinClaIR, Alison, Uncovering the Mind, Manchester, Manchester University Press, 2001, 6 .

3 RoBerts, Gemma, op. cit.

${ }^{4}$ Collado, Jesús Antonio, Kierkegaard y Unamuno. La existencia religiosa, Madrid, Gredos, 1962, 9.

5 SÁNCHEZ-BARBUdo, Antonio, «Una experiencia decisiva: la crisis de 1897», en SÁNCHEZ-BARBURO, Antonio, Miguel de Unamuno, Madrid, Taurus, 1990, 95-122.

${ }^{6}$ CARpio, Adolfo P, «Unamuno, filósofo de la subjetividad», SÁNCHEZ-Barbudo, Antonio (ed.), pp. 123-150.

7 Ardila, J. A. G., «El 'hacer política' de Unamuno y el punto de vista platónicokierkegaardiano», Bulletin Hispanique, 104, 2001, pp. 169-190.

8 Añádase a estos: MESNARD, Pierre y PICARD, Robert, «Aspects noveaux d'Unamuno», La Vie Intellectuelle, 1946, pp. 112-138; MEYER, François, «Kierkegaard and Unamuno», Revue de Littérature Comparée, 29, 1955, pp. 478-492; FASEL, Oscar, «Observations on Unamuno and Kierkegaard», Hispania, 38, 1955, pp. 443-450; SINCLAIR, Alison, «Concepts of Tragedy in Unamuno and Kierkegaard», en Round, Nicholas G. (ed.), Re-Reading Unamuno, Glasgow, University of Glasgow Press, 1989, pp. 121-138; ARANGUREN, José Luis, «Sobre el talante religioso de Miguel de Unamuno», Arbor, 11, 36, 1948, pp. 485503; GARCíA BACCA, J.D., «Kierkegaard y la filosofía contemporánea española», Cuadernos Hispanoamericanos, 2, 1967, pp. 94-105; PALMER, Donald D., «Unamuno’s Don Quijote and Kierkegaard's Abraham», Revista de Estudios Hispánicos, 3, 1969, pp. 295312; USCATESCU, Jorge , «Unamuno y Kierkegaard o la interioridad secreta», Arbor, 103, 1979, pp. 25-40. Sobre la filosofía de Unamuno vide inter alia: PAdilla NovoA, M., Unamuno, filósofo de encrucijada, Madrid, Cincel, 1985; PADILlA NovoA, M., Unamuno (1864-1936), Madrid, Ediciones del Orto, 1994; SÁNCHEZ RuIZ, J.M., Razón, mito y tragedia: ensayo sobre la filosofía de Don Miguel de Unamuno, Zúrich, 1964; PARís, Carlos, Unamuno. Estructura de su mundo intelectual, Valencia, Península, 1968; CEREZO GALÁn, Pedro, Las máscaras de lo trágico. Filosofía y tragedia en Miguel de Unamuno, Madrid, Trotta, 1996.

9 Por ejemplo, Wright, Sarah, «Ethnical Seductions: A Comparatist Reading of Unamuno's El hermano Juan and Kierkegaard's Either/Or», Anales de la Literatura Española Contemporánea, 29, 2, 2004, 119-134, se centra en el influjo de Kierkegaard en 
Ruth Webber el artículo «Kierkegaard and the Elaboration of Unamuno's Niebla» ${ }^{10}$, en que se atribuye la urdimbre novelesca de Niebla a Kierkegaard. Apuntó Webber lo que salta a la vista en la más superficial de las lecturas: que Unamuno siguió, en la composición de Niebla, la novela de Kierkegaard Forførerens Dagbog (i.e. El diario del seductor, traducido al español como Diario de un seductor ${ }^{11}$ ), contenida en la obra Enten-Eller. Las similitudes entre ambas novelas facultaron a Webber a concluir que en Niebla se calcó la estructura narrativa del Diario del seductor. A Webber siguió Jaime Alazraki ${ }^{12}$, quien argumenta que Niebla debe su antirracionalismo a Kierkegaard. Posteriormente, Gemma Roberts, en el capítulo «Los tres estadios de la dialéctica kierkegaardiana en Niebla» ${ }^{13}$ (de su libro Unamuno: afinidades y coincidencias kierkegaardianas) realizó un pormenorizado cotejo de Niebla con la totalidad de la obra del filósofo danés —en palabras de la autora, «omitiendo los aspectos del Diario de un seductor tan minuciosamente considerados» ${ }^{14}$ por Webber-.

La interesante tesis de Webber no parece haber obtenido excesivo eco en la crítica posterior. Hay quienes, como Mario Valdés ${ }^{15}$, han sido remisos a referirse a Webber; por el contrario, prefieren atribuir las particularidades narratológicas de Niebla al Quijote, y las temáticas, a La Celestina. Los argumentos de Roberts tampoco han convencido a los exegetas de Niebla. A pesar de constituir un completísimo estudio de una altura intelectual muy difícil de superar, el trabajo de Roberts apenas aspira, en palabras de la autora, a «efectuar un acercamiento a la temática de Unamuno, a través de las coincidencias que la enlazan al pensamiento del filósofo danés» ${ }^{16}$, esto es, de señalar meras coincidencias sin determinan si se deben a un influjo consta-

El hermano Juan y apunta: «A comparative reading of Unamuno's El hermano Juan with Kierkegaard's Either/Or will draw out themes common to both: forms of love and the amatory cure; free-will (represented by choice); the angst of human finitude and the queso for immortality; the trensions between binary oppositions and triadic dialectical discourses; religión as a 'leap of faith'».

${ }^{10}$ WeBber, Ruth House, «Kierkegaard and the Elaboration of Unamuno's Niebla», Hispanic Review, 32, 1964, pp. 118-134.

${ }^{11}$ El uso, por parte de Kierkegaard, de un artículo determinado en lugar de uno indeterminado es matiz que no debiera soslayarse.

${ }_{12}$ Alazraki, Jaime, «Motivación e invención en Niebla de Unamuno», Romanic Review, 58, 1967, pp. 241-253, 242.

${ }^{13}$ ROBERTS, Gemma, op. cit., 25-77.

14 Ibídem, 25.

15 VALDÉS, Mario J., «Introducción», en Miguel de Unamuno, Niebla, Madrid, Cátedra, 2005, pp. 9-59, 34-36.

${ }^{16}$ RoBERTS, Gemma, op. cit., 13. Y señala más adelante: «Mi propósito no será tampoco buscar la influencia directa de Kierkegaard en Unamuno, sino contrastar ciertos temas y motivos filosóficos y literarios de Niebla con el pensamiento kierkegaardiano que los precede, y que, de varias maneras, contribuye a aclarar el sentido existencial de dicha novela». 
table, a la similitud de pareceres o a la mera casualidad ${ }^{17}$. Como he apuntado, Roberts apenas se fija en el Diario del seductor, sino que sus argumentos proceden del resto de las obras capitales de Kierkegaard. Las razones que expliquen esta remisión de la crítica por reconocer lo kierkegaardiano en Niebla pueden deberse a muchas causas — quizá a que el estudio de Kierkegaard en relación a Unamuno no haya sido acometido por filólogos, sino por filósofos que estaban más interesados en su obra filosófica-. Mas lo cierto es que el Diario del seductor de Kierkegaard es una obra capital en la historia de la literatura, una ilustre fuente literaria para Niebla, una novela que se cuenta entre las obras de ficción más veneradas por la crítica escandinava y cuya recepción, en Escandinavia, fue (y sigue siendo) impar ${ }^{18}$. Aparte de ello, la principal causa, a mi entender, estriba en que Webber yerra en sus conclusiones: a creer de esta crítica, las evidencias textuales certifican, groso modo, que el Diario del seductor y Niebla poseen una estructura diegética común, cuando no es ese el caso (vida infra).

No obstante lo afirmado por Webber, la impronta kierkegaardiana en Niebla alcanza lo filosófico en general y lo existencial y escatológico en particular. Leyendo la novela de Unamuno a la luz del Diario del seductor y de Del sentimiento trágico de la vida (obra con la cual guarda enjundiosas afinidades, cf. infra) se percibe en Niebla un complejo y trascendental trasfondo filosófico. Kierkegaard estampa su marchamo en Niebla doblemente: a través de la influencia directa ejercida con el Diario del un seductor e, indirectamente, mediante su influjo en Del sentimiento. En este trabajo explicaré, en primer lugar, el grado exacto de relación intertextual que media entre Niebla y el Diario del seductor (revisando y ampliando considerablemente los argumentos de Webber) y, en segundo, las coincidencias entre Niebla y Del sentimiento; en función de todo lo cual ofreceré una nueva lectura de la novela española, una nueva interpretación a la luz de las filosofías de Kierkegaard y de Unamuno: que, como se indica en Niebla, «es el amor el consuelo en el desconsuelo, es la única medicina contra la muerte» ${ }^{19}(165)$.

Aparte de las agudas observaciones expresadas por Webber y Roberts, Niebla ha sido objeto de numerosas incursiones críticas en el ámbito de la intertextualidad; en especial han proliferado los estudios que la emparientan con $\mathrm{El}$

${ }_{17}$ Procedimiento cuya conveniencia apuntó BACHELOR, R.F., en Unamuno Novelist. A European Perspective, Oxford, Dolphin, 1972, 37: «A consideration of the influence Kierkegaard exercized on Unamuno does not seem very profitable, but what is beneficial, I think, as with Nietzsche, is the establishing of striking similarities».

${ }_{18}$ Vide, inter alia, Bo Kampmann Walther, «Sækulariseret apokalypse. Et essay om forvitret retorik og billedsprog i Søren Kierkegaards Forførerens Dagbog», Rhetorica Scandinavica, 2, pp. 36-53, SANDERS, Karin, «Blik og forførelse. Om Søren Kierkegaards Forførerens Dagbog», KRITIK, 86, 1988, pp. 54-63.

19 Todas las referencias provienen de la vigésima edición de Cátedra, Madrid, 2005. 
amigo Manso de Galdós ${ }^{20}$ y con el Quijote ${ }^{21}$. Webber señaló la existencia, en la biblioteca de Unamuno, de una traducción italiana del Diario del seductor, que data de $1910^{22}$. Considerando que Unamuno comenzó la redacción de Niebla en 1907 y que incluso la gestó hacia 1900, el dato de Webber pierde relevancia. Así las cosas, Sánchez-Barbudo advierte que en una carta a Clarín de 1900 Unamuno declara: «Voy a chapuzarme en el teólogo y pensador Kierkegaard». Estima Sánchez-Barbudo que «De Kierkegaard [...] se pueden encontrar reminiscencias evidentes ya en los ensayos de Unamuno en los años 1903 y 1904» ${ }^{23}$. También trae a colación este crítico una carta de esa época, en que Unamuno declara que «Para perfeccionarme en el dano-noruego o norso-danés pedí la obra de Brandes sobre Kierkegaard» ${ }^{24}$. Lo cierto es que las obras completas de Kierkegaard en danés que Unamuno compró y escolió -i.e. las editadas en catorce volúmenes por A. B. Drachmann y J.L. Heiberg - se publicaron en Copenhague a partir de 1901 y hasta $1906^{25}$. Unamuno fue comprando cada uno de los volúmenes conforme iban viendo la luz. En definitiva, es notorio que a partir de $1901^{26}$ Unamuno leyó a Kierkegaard en danés, por sus conocimientos de lenguas cognadas, o porque, como declaró, puso cierto esmero en aprender esta lengua de modo que pudiese leer a Kierkeggard; como también es claro que en el filósofo de Copenhague halló el más poderoso contrapunto al positivismo de $\mathrm{Hegel}^{27}$. Tanto es así que, en 1932, al prologar San Manuel

${ }^{20}$ En concreto: BERKOwITZ, H.C., «Unamuno's Relations with Galdós», Hispanic Review, 8, 1940, pp. 321-338; GILlET, Joseph E., «The Autonomous Character in Spanish and European Literature», Hispanic Review, 24, 1946, pp. 179-190; LivingSTONE, Leon, «Interior Duplication and the Problem of Form in the Modern Spanish Novel», PMLA, 73 (1958), pp. 393-406.

${ }^{21}$ KING, W.F., «Unamuno, Cervantes y Niebla», Revista de Occidente, 16, 1967, pp. 219-231; LEBOIS, A., «La révolte des personages: de Cervantes à Raymond Schwabi», Revue de Littérature Comparée, 23, 1949, pp. 248-295; Blanco AguinagA, Carlos, «Unamuno's Niebla: Existence and the Game of Fiction», Modern Language Notes, 89, 2, 1964, pp. 188-205; FRIEDMAN, Edward H., Cervantes in the Middle. Realism and Reality in the Spanish Novel from Lazarillo de Tormes to Niebla, Newark, Juan de la Cuesta, 2006.

${ }^{22}$ KIERKEGAARD, Søren, Il diario del seduttore, Torino, 1910. Estima SinclaIR, Alison, Uncovering the Mind, op. cit., 230, que «If heavy annotation is a mark of appreciation, a work Unamuno clearly appreciated was Kierkegaard's Either/Or». La anotación extensa puede reflejar admiración o, también, reprobación, dependiendo de la naturaleza de las glosas. Sirva el apunte de Sinclair, no obstante, para dejar constancia de que Unamuno leyó con profunda atención el Diario del seductor.

${ }^{23}$ Citado en SÁnChEZ-BARBUdo, Antonio, op. cit., pp. 113.

24 Loc. cit.

${ }^{25}$ Cf. VAldÉs, Mario J., An Unamuno Source Book, Toronto, University of Toronto Press, 1973, xx, nota 7.

${ }^{26}$ Como apuntó, antes de Valdés, MEYER, François, op. cit., pp. 479-480, y después incidió en ello, Collado, Jesús Antonio, op. cit., pp. 388.

27 Johnson, Roberta, Crossfire. Philosophy and the Novel in Spain, 1900-1934, Lexington, The University Press of Kentucky, 1993, p. 93, estima que Unamuno comenzó a leer a Kierkegaard hacia 1901: «Most importantly Kierkegaard's personalist philosophy, 
Bueno, mártir y tres historias más, Unamuno se refería a Kierkegaard en los siguientes términos: «he acabado de leer la obra: $O$ lo uno o lo otro (EntenEller) de mi favorito Soeren Kierkegaard». Enten-Eller contiene el Diario del seductor y a ella se refiere Unamuno en el ensayo «Ibsen y Kierkegaard» de 1907. En cualquier caso, Unamuno, al chapuzarse en Kierkegaard, habría de haberse topado, muy seguramente en danés, con el Diario del seductor, que es la principal de sus obras de ficción. Las coincidencias sin número apuntadas por Webber, junto a otras que aquí explicaré, dejan constancia de ello.

\section{NiEbla y EL DiaRIO DE UN SEDUCTOR DE KIERKEGAARD}

En su trabajo, Webber relaciona Niebla al Diario del seductor en virtud de las siguientes coincidencias: 1) los títulos, 2) el molde narrativo, 3) el enamoramiento a primera vista, 4) la imposibilidad de los enamorados de recordar la imagen de la amada, 5) el modo en que ambos protagonistas enuncian el nombre de sus damas, 6) la situación familiar de estas y 7) la relación de los enamorados con las tías de sus amadas, además de 8) una serie de motivos e imágenes.

Utilizando una traducción inglesa ${ }^{28}$, Webber observa que el título de Enten-Eller se corresponde con el de Niebla: Either/Or. A Fragment of Life. Edited by Victor Eremita y Niebla. Nivola. Prólogo de Víctor Goti. (El título original en danés es Enten-Eller; et livs-fragment. Udgivet af Victor Eremita, en español «O-o; un fragmento de vida. Editado por Víctor Eremita»). En ambos títulos se resalta la presencia del prologuista, que en ambos textos lleva el mismo nombre de pila. En efecto, al Diario del seductor precede un prólogo en que un conocido de los enamorados relata las circunstancias en que el texto se dio a la imprenta. El juego metaficcional que Unamuno desarrolla en Niebla se demuestra, no obstante, considerablemente más intricado. La función del prologuista danés se limita a recopilar el diario escrito por el protagonista y precederlo con cuatro cartas escritas por la enamorada (de nombre Cordelia) después del desenlace de la historia.

Ambos textos, aduce Webber, adoptan la forma narrativa de un diario. La novela de Kierkegaard se compone del prólogo, de las cartas de Cordelia

which Unamuno began reading in 1901 and continued to devour through 1906 as new volumens became available, provided him with a substitute for the rationalism and positivism he had discarded». ILIE, Paul, en Unamuno: An Existential View of Self and Society, Madison, University of Wisconsin Press, 1967, p. 5, estima que la filosofía de Unamuno se muestra considerablemente más afín a Kierkegaard y a Nietzsche que a Heidegger, Jaspers y Satre.

${ }^{28}$ KierkegaARD, S., Either/Or, David F. Swenson y Lillian M. Swenson (trad.), Nueva York, Anchor Books, 1959. En mi exposición, seguiré la traducción española Diario de un seductor, Barcelona, Ediciones 29, 1989. Ha de considerarse, no obstante, que Unamuno habría leído el original en danés. 
y del diario per se, dividido en entradas con sus fechas como encabezados. El narrador prescinde progresivamente de estas datas, hasta que desaparecen por completo. Difiero de la analogía apuntada por Webber. Niebla, sensu stricto, carece de este molde, sino que, como expresa Víctor Goti en el cuerpo del relato, Niebla adopta, de ordinario, forma de diálogo. Un buen número de episodios son soliloquios de Augusto Pérez, que discurre incesantemente acerca de las posibilidades que se le presentan. Esos soliloquios se tornan monólogos con la aparición de Orfeo. De modo muy cervantino, Unamuno introduce en la narración a un personaje que haga las veces de receptor de los discursos enunciados por el protagonista. En lo que, sin embargo, la profesora norteamericana no reparó es en la palmaria correspondencia de las psicologías de los narradores. El Diario del seductor es el soliloquio (escrito) de Johannes. En esta obra, el lector asiste a cuantos pensamientos cruzan la mente del seductor (cf. infra). En esto estriba la correspondencia más importante entre estas dos narraciones, en las análogas psicologías de los protagonistas —como explico a continuación-.

Entre las situaciones del texto danés que se repiten en el español reseña Webber el enamoramiento a primera vista. En el Diario del seductor, Johannes, de súbito, repara en Cordelia:

Estaba paseando por la «Línea Larga», sin prestar aparentemente atención al mundo que me rodeaba: pero, por el contrario, nada escapaba a mis encantadores ojos... La vi. La mirada, negándose a obedecer por más tiempo la voluntad de su dueño, se quedó fija en ella.

No pude realizar el menor movimiento: no veía, pero sí miraba con ojos abiertos de par en par, que se clavaban en ella. El ojo, cual el esgrimista que se queda irreductible en su sitio, permanecía firme, petrificado en la dirección tomada. No pude bajarlos, me resultó imposible ocultar mi mirada, no conseguí ver nada, pues estaba viendo demasiado.

Lo único que me quedó grabado en la mente fue una capa verde que ella lucía. Y nada más. Lo mismo que aquel que vio las nubes en lugar de la diosa Juno (27-28).

Al igual que el seductor danés, Augusto queda prendado de Eugenia al verla en uno de sus errabundos paseos: «En esto pasó por la calle [...] una garrida moza, y tras de sus ojos se fue, como imantado y sir darse de ello cuenta, Augusto» (110). Mas, sobre la similitud del paseo y el enamoramiento a primera vista, pesan los párrafos que, en cada uno de estos dos textos, preludian sendos pasajes (lo que no señala Webber). En Niebla, Augusto discurre larga y pausadamente acerca de la estética de un paraguas. En el Diario del seductor, Johannes divaga en torno a la estética de unos pies de mujer que descienden de un carruaje:

¡Cuidado, mi bella desconocida! ¡Cuidado! No es tan sencillo descender de un coche; en ocasiones, puede ser un importante paso. Con frecuencia, están tan mal colocados los estribos, que es preciso dejar a un lado la elegancia para salir 
sin inconvenientes. A veces, sólo es posible salvarse con un alocado salto en brazos del cochero o del lacayo. Cocheros y lacayos... ¿qué bien les va?

Hay momentos que siento el deseo de entrar como sirviente en una casa donde haya señoritas jóvenes. ¿Qué fácil le resulta a un criado penetrar en los secretos de su casa!

Pero, ipor amor de Dios, no baje tan precipitadamente de su coche! iSe lo ruego!; iya es de noche! No deseo molestarla, por lo que me oculto detrás de un farol, para que no me pueda ver: con sólo saber que nos miran nos sentimos perplejos o embarazados. ¡Ahora puede bajar! ¡Permita que el lindo piececillo, cuya gracia tanto admiro, se arriesgue por el mundo! ¡Ánimo! Ya está seguro de encontrar terreno firme. ¿Acaso aún teme a algún espectador molesto? No creo que sea del cochero ni tampoco de mí..

Acabo de ver su piececito y, cual naturalista de la escuela de Cuvier, saqué mis conclusiones. ¡Rápido, pues! ¡Cómo mi ansiedad aumenta su belleza! Pero no, el temor no es hermoso por sí mismo si no va acompañado por el deseo de dominarlo. ¡Al fin! ¡Con qué seguridad se asienta su diminuto pie! (17).

A partir de estos pensamientos, Johannes dedica las dos primeras entradas del diario a relatar sus cavilaciones acerca de las mujeres. En la segunda entrada explica cómo concibe al detalle un esquema con el objeto de entablar conocimiento con una muchacha en un museo.

De otro lado, Niebla comienza con las meditaciones de Augusto en cuestiones estéticas: a Augusto incomoda la lluvia por cuanto le obliga a abrir su paraguas que, considera, « ¿Estaba tan elegante, tan esbelto, plegado y dentro de su funda! Un paraguas cerrado es tan elegante como es feo un paraguas abierto» (109). Y discurre a renglón seguido: «Es una desgracia esto de tener que servirse uno de las cosas [...] tener que usarlas. El uso estropea y hasta destruye toda belleza» (109). Augusto aún no piensa en las mujeres, porque, a diferencia de Johannes, no es un seductor experimentado. La obsesión por perseguir damitas nubiles, idéntica a la que relata el narrador al principio del Diario del seductor, le llegará después de haber conocido a Eugenia (vide infra). Está preocupación estética de Augusto coincide con la de Johannes, quien declara «Yo soy un esteta» (70), exalta sus «principios estéticos» (81) y alude a sus «deberes hacia la estética» $(133)^{29}$.

Henos, en definitiva, no solo ante dos situaciones similares, sino ante dos personajes idénticos en su posición filosófica ante el mundo: absortos en sus pensamientos y apartados volitivamente del mundo que los circunda, ambos divagan en torno a cuestiones estéticas inspiradas por objetos cotidianos. Tras el enamoramiento a primera vista, ambos pasan del impulso platónico al razonamiento ${ }^{30}$, o, en palabras de Johannes: «quod ante fuit

${ }^{29}$ RoBERTS, Gemma, op. cit., 27-28: «Augusto es un contemplativo [...] la descripción unamuniana de Augusto Pérez en posición inmóvil y estatuaria se ajusta simbólicamente a estas palabras del filósofo danés» [en la segunda parte de Enten-Eller].

${ }^{30}$ Como es notorio, tanto Unamuno (una vez que superó el positivismo) como Kierkegaard fundamentan sus divagaciones en métodos irracionalistas. Por razonamiento significo el ejercicio intelectual de razonar, como así se significa en el Diario del seductor. 
impetus nunc ratio est» (57), al uso premeditado de la «dominadora razón» (62). Todo en el danés se sojuzga a la premeditación más minuciosa: estudia agronomía para poder mantener conversaciones con la tía de Cordelia, incluso hace que Eduard corteje a Cordelia con el fin de que ella se percate de que Johannes es mejor que otros hombres, discurre acerca de cómo acceder a la casa y declara que «yo siempre actúo con método» (88). A pesar de ser un novicio en cuestiones de amor, Augusto divaga acerca de cómo llegar a Eugenia: se gana a los tíos además de a la portera y aspira a demostrar su amor pagando la hipoteca de Eugenia ${ }^{31}$.

Johnson estima que el idealismo de Augusto refleja las filosofías de Descartes y de $\mathrm{Kant}^{32}$, al tiempo que se encuentra como una serie de alternativas filosóficas ${ }^{33}$. Sin embargo, ese ímpetu por el razonamiento, de apariencia cartesiana y kantiana, forma parte del irracionalismo de Augusto, quien, como Johaness, demuestra que la razón fracasa en su intento por comprender el mundo ${ }^{34}$. En efecto, el protagonista deforma el lema de Descartes al afirmar y proclamar «Amo, ergo sum» y «Edo, ergo sum». Como ha apuntado Germán Gullón ${ }^{35}$, Unamuno ensaya en Niebla la técnica narrativa de la corriente de conciencia, mediante la cual un personaje expresa sus sentimientos de modo desordenado y sometido al subconsciente. Esto es, que los razonamientos de Augusto acusan desorden y se escapan a lo consciente, y, por ello, se evaden de la razón cartesiana y kantiana. Esta correspondencia en el método de pensamiento en Augusto y Johannes establece el vínculo más relevante y trascendental para el desarrollo de la narración y del mensaje filosófico de Niebla. La dialéctica de Augusto es, pues, una transposición de la de Johannes.

Relacionado con los razonamientos de ambos personajes se hallan sus sendas predisposiciones a la experimentación filográfica. Augusto, ignorante que es en cuestiones de amor, decide tomarse la seducción de Eugenia como un experimento psicológico. Johannes, a pesar de las muchas aventuras vi-

31 Sobre la personalidad de Augusto vide, RIBBANS, Geoffrey, «La evolución de la novelística unamuniana: Amor y pedagogía y Niebla», en Niebla y soledad: aspectos de Unamuno y Machado, Madrid, Gredos, 1971, pp. 108-142; BlANCO AguinagA, Carlo, op. cit.

32 JOHNSON, Roberta, op. cit., p. 92.

33 Ibidem, p. 97.

${ }^{34}$ Por ello entiende BRETZ, Mary Lee, Encounters Across Borders. The Changing Visions of Spanish Modernism, 1890-1930, Lewisburg, Bucknell University Press, 2001, que Augusto recorre un «existential journey» (515) y que «Augusto's process involves the gradual overthrown of traditional authoritative discourses and the evolution of his own personal but still polyphonic mode of speaking and thinking» (336).

${ }^{35}$ Gullón, Germán, «Introducción», en Miguel de Unamuno, Niebla, Madrid, EspasaCalpe, 2006, p. 27: «penetramos [los lectores] en la cabeza, en los pensamientos de los personajes directamente, bien sea mediante el uso del soliloquio, bien, sobre todo, del monólogo interior y en la corriente de conciencia, técnica en cuyo uso Unamuno antecede a Joyce (Bloom) y a Faulkner (Benji)». 
vidas, declara en varias ocasiones que experimenta con Cordelia: «Ayer por la noche me propuse poner a prueba lo expansivo del espíritu de Cordelia» (66), lo que le hace rememorar «la prueba entre audaz y alocada que hice con una dama muy distinguida» (68), y se refiere al proceso de seducción de Cordelia como «exploraciones [...] en su alma» (72). Y estos experimentos de Johannes y Augusto acaban, hasta cierto punto, en lo mismo: piensa Augusto que «me han pescado entre todos» (256) y escribe Johannes que «nada ocurrió como yo lo esperaba» (77).

Naturalmente, estos personajes difieren entre sí en sus respectivos contextos: Johannes es un seductor consumado; Augusto, un novicio. Mas, a pesar de su empaque donjuanesco, el galán de Copenhague acaba enamorándose sinceramente de Cordelia:

Conozco muy bien las distintas etapas del amor, pero, sin embargo, jamás experimenté una angustia tan palpitante como para perder el dominio de mí mismo.

$\mathrm{Y}$ no es que esa sensación no me resulte desconocida, sino que en mí obra de forma distinta, porque, en cambio, me fortalece. ¿Quizás es que hasta hoy no estuve realmente enamorado? Puede ser (56).

Pasado el mediodía de la novela, Johannes declara: «¿Amo a Cordelia? ¡Sí! ¿Con toda sinceridad? ¡Sí!» (86). En esto coinciden también los protagonistas de Niebla y del Diario del seductor: en sufrir un amor verdadero, irracional y de reminiscencias románticas. (Irracional es, porque este amor verdadero fractura la existencia de los protagonistas: Johannes no conocía el amor, pues seducía sin amar; a Augusto era ajeno el amor). Podría decirse que los protagonistas de estas dos novelas difieren el uno del otro por cuanto el danés es un seductor que seduce y el español carece de experiencias amatorias y, por ello, acaba siendo seducido o, como él declara, «pescado» (256). No obstante lo cual, el prologuista del Diario del seductor asevera que «El mismo amor que por Cordelia sentía estaba tan lleno de complicaciones, que a causa de ellas parecía [Johannes] ser el seducido» (10).

Y el amor despierta la predisposición de ambos a la admiración de la estética femenina: escribe Johannes que «Se puede estar enamorado de muchas mujeres a la vez, puesto que se ama en grado distinto las distintas cualidades que cada una posee» (64), «Creo en todo, absolutamente en todo, hasta en milagros, tan sólo para tener pruebas de que la única y última cosa del mundo digna de que la admire y de que me asombre es una muchacha» (93), «Mis ojos jamás se cansan de contemplar las irradiaciones de la belleza femenina, infinitas y dispersas. Cada muchacha es una de ellas y aun siendo una parte, es un ser completo en sí mismo y por eso feliz, alegre y bello» (126). Augusto exclama: «Pero ¡cuántas mujeres hermosas hay en este mundo, Dios mío! ¡Casi todas! ¡Gracias, Señor, gracias: gratias agimus tibi propter magnam gloriam tua! ¡Tu gloria es la hermosura de la mujer, Señor! Pero ¡qué cabellera, Dios mío, qué cabellera!» (154) y el narrador in- 
dica al poco que el protagonista «Clavó un momento sus ojos sedientos de hermosura» (155) en una pareja de mozas.

En esto, Augusto se asemeja también a Manrique, el protagonista de «El rayo de luna» de Bécquer. En la leyenda del autor sevillano se le describe de esta guisa: «¡Amar! Había nacido para soñar el amor, no para sentirlo. Amaba a todas las mujeres un instante: a ésta porque era rubia, a aquélla porque se cimbreaba, al andar, como un junco» ${ }^{36}$. En este rasgo, tomado a todas luces del texto decimonónico, confirma a Augusto como un personaje profundamente romántico. Apenas unos párrafos después, Augusto mantiene una conversación con Víctor en que le informa:

-...ayer la vi en su casa, con pretexto de visitar a sus tíos; la vi...

-Y te miró, ¿no es eso? ¿Y creíste en Dios?

-No, no es que me miró, es que me envolvió con su mirada; y no es que creí en Dios, sino que me creí un dios (156).

Víctor alude a la rima de Bécquer:

Hoy la tierra y los cielos me sonríen

Hoy llega al fondo de mi alma el sol,

Hoy la he visto... la he visto y la he mirado...

¡Hoy creo en Dios!

En su respuesta a Víctor, Augusto sublima la idealización romántica de la rima. Así, mientras que la musa de Bécquer mira y con su mirada constata la existencia de Dios, la mirada de Eugenia adquiere más vida y actúa envolviendo a Augusto, quien en virtud de tamaña gracia se cree un dios. Unamuno imposta e hiperboliza la estética becqueriana y, de este modo, hace de su protagonista una sublimación de lo romántico.

Apunta Webber que, al igual que Johannes, Augusto no atina a recrear la imagen de su enamorada después de haberla visto por primera vez. Johannes apenas recuerda la capa verde que vestía Cordelia; Augusto barrunta angustiado: «¿Se borrará su imagen de mi memoria? Pero ¿cómo es? ¿Cómo es la dulce Eugenia? Sólo me acuerdo de unos ojos... Tengo la sensación del toque de unos ojos... Mientras yo divagaba líricamente, unos ojos tiraban dulcemente de mi corazón» (112).

Asimismo, como señala Webber, tanto Johannes como Augusto se recrean en la pronunciación de los nombres de sus respectivas enamoradas. Exclama Augusto: «Eugenia, Eugenia, Eugenia, mi Eugenia, finalidad de mi vida» (120); escribe Johannes:

¡Cordelia! ¡Qué nombre tan maravilloso! En casa practico pronunciarlo y repito con frecuencia, hora tras hora, seguidamente:

— ¡Oh, Cordelia! ¡Cordelia, mi Cordelia, mi Cordelia! (49).

\footnotetext{
${ }^{36}$ BÉCQUER, Gustavo Adolfo, Leyendas, Madrid, Bruño, 1991, p. 227.
} 
A este apunte de Webber han de añadirse dos observaciones. Primero, que cuantas reflexiones el nombre de Eugenia inspiran a Augusto -i.e. la concordancia de nombre y apellido (112-113) — recuerdan asimismo el análisis que Johannes ensaya del nombre de Cordelia: «`Cordelia!, ¡Un nombre maravilloso, en realidad! También se llamaba así la tercera hija del rey Lear, aquella hermosa virgen cuyo corazón no estaba en los labios, porque sus labios eran mudos, aunque el corazón palpitase con tanto ardor. Así es también mi Cordelia» (42). Segundo, el uso de adjetivos posesivos con los nombres propios. Luciano González Egido $^{37}$ ha observado el uso de los posesivos en el estilo de Unamuno. A lo apuntado por Webber cabe añadir también que, en Niebla, el adjetivo posesivo mi acompañando a Eugenia podría deberse al influjo del Diario del seductor, donde el narrador se refiere a «mi Cordelia» repetidamente (supra); Johannes comienza todas las cartas que escribe con el encabezado «Mi Cordelia» y las firma como «Tu Johannes».

Repara Webber en que el entorno social de Eugenia guarda semejanza con Cordelia. La danesa es hija huérfana de padre y madre — del progenitor se especifica que fue capitán de la armada- y reside con su tía paterna. Los padres de Eugenia también han fallecido y ella vive con sus tíos. Webber no establece más similitudes porque, en apariencia, no las hay, con una excepción (que no apunta Webber): que Cordelia toca el piano. Ello no parece producto de la casualidad, pues las coincidencias no se limitan a eso: Eugenia da clases de piano, pero aborrece este instrumento; de Cordelia escribe Johannes que «no toca ningún instrumento» (50), pero, en el siguiente párrafo, descubre que «allí sola, sentada ante el piano [...] tocaba una melodía sueca» (50) a escondidas. Esto es, que tanto una como otra se distancian en uno $\mathrm{u}$ otro sentido del piano. Conviene observar asimismo que Eugenia es un personaje atípico en la sociedad española de principios del siglo XX. Su tía la califica de «feminista» (187) y ella misma se declara «anarquista» (139), que son marbetes harto inusuales para una mujer española en 1907-14; posee, a más, el ingenio y la fuerza precisos para dominar a Augusto y conseguir casarse con quien a ella más le place. De Eugenia se puede afirmar lo mismo que Johannes afirma de Cordelia, que «Hay en ella una fuerza, una energía, semejante a la de una valkiria» (122). Esta independencia, estas apostura y determinación, no son en absoluto típicas de la mujer española de hace una centuria. Muy por el contrario, Eugenia recrea la imagen de la mujer nórdica que Ángel Ganivet describió en sus Cartas finlandesas, donde presenta a las jovencitas escandinavas como independientes y centradas en sus profesiones ${ }^{38}$. Es muy improbable que Unamuno no conociese

${ }^{37}$ GonZÁLEZ EgIDO, Luciano, «Introducción», en Miguel de Unamuno, En torno al casticismo, Madrid, Espasa-Calpe, 1998.

${ }^{38}$ GANIVET, Ángel, Cartas Finlandesas y Hombres del Norte, Madrid, Espasa-Calpe, 1998, pp. 116-117: «Todas [las finlandesas] tienen su profesión, porque aquí la mujer 
las Cartas finlandesas de su amigo Ganivet, en cualquier caso, el carácter de Eugenia se corresponde, alrededor de 1910, con el de una joven nórdica.

Por último, indica Webber que tanto en Niebla como en el Diario del seductor, los protagonistas se ganan la confianza y el aprecio de las tías de sus damas. Por su holgada posición social, Augusto es el partido idóneo a ojos de la tía, para quien el matrimonio debe sustentarse sobre unas garantías sociales y económicas (184). La tía de Cordelia disfruta de la conversación de Johannes y celebra el compromiso.

Al cúmulo de coincidencias sugeridas por Webber (a que debe sumarse las que aquí se han apuntado), añade esta crítica que hay «numerous motifs and images common to both works» ${ }^{39}$, aseveración que debe tomarse mucho más en serio de lo que, quizá, ella misma creyese, porque esas coincidencias, además de ser miríada, en algunos casos guardan una preciosa significación para el entendimiento de Niebla. Por ello, los párrafos siguientes profundizarán en el influjo de la novela danesa en la española.

Existen en la novela de Unamuno afirmaciones que se corresponden con otras del Diario, v.g. que los hombres «no se enamoran de veras sino cuando él ve que ella mira a otro hombre o ella le ve a él mirar a otra mujer» (206), como aparece en Niebla, es una sumaria paráfrasis de la sentencia de Johannes:

El amor lo es todo: por eso para el alma enamorada cualquier otra cosa tiene solamente la importancia que le da el amor.

Si un prometido pensara más en otra joven que en su futura esposa, despertaría en esta hora, como si hubiese cometido un crimen, y él mismo se sentiría culpable de tal crimen. Si tú, en cambio, advirtieras algo parecido con respecto a mí, no verías en eso más que un homenaje, pues sabes muy bien que para mí iba a ser imposible amar a otra que no fueses tú (139).

Sorprende asimismo encontrar en el Diario del seductor un personaje de nombre «Augusto» (20), que se filtra en los devaneos filográficos de Johannes, y que el nombre de Eugenia comparta la resonancia de Cordelia (toda vez que riman en asonante y poseen el mismo número de sílabas).

De Niebla escribió Unamuno: «Quiero hacer una rechifla amarga y fundir, no yuxtaponer meramente, lo trágico, lo grotesco, lo sentimental», una «novela pedagógico-humorística» ${ }^{40}$. Y Niebla bien pudiera definirse como una suerte de tragicomedia magistral, en que se funden, como pretendía su au-

trabaja como el hombre [...] Ocurre, pues que las mujeres estudian para ganar dinero, y después que entran en la vida exterior y mecánica sufren la presión de la rutina y pierden las actitudes estéticas, naturales en la mujer que hace cosas femeninas, como leer, coser, bordar, cuidar los pájaros, regar las macetas o pelar la pava». Roberts, Gemma, op. cit., 46, considera a Eugenia «una mujer esencialmente burguesa».

${ }^{39}$ WeBber, Ruth House, op. cit., p. 123.

${ }^{40}$ Citado en VAldÉs, M.J., op. cit., p. 51, 52. 
tor, lo ominoso con lo cómico ${ }^{41}$. El Diario del seductor de Kierkegaard rezuma esa misma concomitancia de lo fatídico con lo humorístico, porque, como ha apuntado Edward Friedman ${ }^{42}$ respecto de Niebla, la risa antecede la tragedia. Reflexionando acerca de la posibilidad de que Cordelia tenga novio afirma Johannes: «Un novio no es más que una dificultad cómica» (33) y, en efecto, el ingenio de Johannes propicia que las acciones de Eduard se tornen cómicas a lo largo de toda la novela. Estando Johannes apostado en el balcón de una casa esperando a que pase Cordelia, con el único propósito de recrearse en su imagen, repara en que le urge echarse a la calle para no perderla de vista. Y al apresurarse tropieza, en el salón, con una señora que le ofrecía té. Escribe en el diario: «Oigo un grito de espanto, pero en ese momento sólo pienso en el modo de liberarme; y para justificar con una broma mi retirada digo con voz patética: 'Igual que Caín, quiero huir del lugar en el que vertí este té’»(39). A su ánimo cómico sigue una situación verdaderamente cómica: «Pero, como si todo se conjurase contra mí, al dueño de la casa se le ocurre tomar en serio mis palabras y el buen hombre declara que no va a dejarme salir si antes no me tomo el té» (3940). En cierta ocasión ironiza, disertando acerca de qué es un beso, que «sirve a maridos y mujeres para limpiarse la boca a falta de servilletas» (115). En otra se interesa por lo que habla un grupo de ocho muchachas de entre dieciséis y veinte años, y contrasta el embargo sentimental que experimenta con el tedio que le produciría una reunión de mujeres casadas, en la cual «se ocupan de cosas sin importancia, como por ejemplo, si es mejor pagar al carnicero todos los días o a fin de mes» (119).

Pero, sobre cualesquiera coincidencias pesa con firmeza apabullante la existencia nebulosa de ambos protagonistas. Augusto declara que la vida es niebla (115): «esas penas y esas alegrías vienen embozadas en una inmensa niebla de pequeños incidentes. Y la vida es esto, la niebla» (115), pensamiento que se repite a lo largo del texto. Aun cuando Johannes no defina la

${ }^{41}$ JoHnSON, Roberta, op. cit., p. 93 estima que «The heightened comic tone no doubt derives from Unamuno's fervent reading of the English novels in the first decade», y transcribe (204, nota 13) algunas glosas de Unamuno a The Life and Adventures of Martin Chuzzlewit. No reconozco, empero, cómo estas anotaciones de Unamuno pueden servir para argumentar que el tono cómico de Niebla se debe exclusivamente a las letras inglesas. El tono tragicómico del Diario del seductor me parece mucho más semejante. Gemma Roberts, op. cit., atribuye el humor de Niebla coincide con el «humor melancólico» típico de las obras de Kierkegaard. Sobre el humor en Niebla vide., FRANZ, Thomas R., «El sentido del humor y adquisición de autoconciencia en Niebla», Cuadernos de la Cátedra Miguel de Unamuno, 23, 1973, pp. 5-25, donde se apunta: «El efecto total de este abundante sentimiento humorístico en Niebla es el de señalar el abyecto castigo a los esfuerzos racionales del hombre por encontrar significación a la vida, esfuerzos e intentos que son invariablemente cómicos dada la absurda discrepancia existente entre la medida o magnitud de la empresa y la debilidad o anemia de los recursos del hombre» (7).

${ }^{42}$ FRIEDMAN, Edward H., op. cit., p. 258: «laughter is a preparation for tragedy». 
vida como una niebla, en su diario denota esta misma concepción vital: el prologuista afirma que «También yo me siento arrastrado en aquella zona nebulosa, en aquel mundo de ensoñación, donde nuestra misma sombra nos asusta a cada instante» (13), y Johannes escribe: «Adorable hechicera, hada o genio, disipa la niebla que te envuelve, descúbrete, pues sin duda estás aquí, pero resultas invisible» (23), y que se quedó «lo mismo que aquel que vio las nubes en lugar de la diosa Juno» (28), que el paso del tiempo en ausencia de Cordelia «me entristece y me perturba, nublándome la vista» (30), que «muchas jovencitas tienen en el corazón una imagen indefinida y nebulosa, que debería ser un ideal, y por tal imagen miden a todos los objetos de su amor» (79), que «lo veo todo sumergido como en un mar de niebla» (99). Por otro lado, Cordelia, en la carta que escribe al prologuista declara que «al abrazarle [a Johannes], todo desaparecía y con mis brazos solo ceñía 'las nubes'» (13). La imagen de la niebla, que impide a Augusto moverse con seguridad por el mundo, se halla ligada a la temática de la existencia. Es central en la novela de Unamuno el tema de la existencia, tema complejo en que me detendré más adelante. Mas adviértase que en el prólogo del Diario del seductor se presenta a Johannes sumido en ese mismo nimbo a medio camino entre la existencia y la inexistencia que en los últimos capítulos de Niebla se torna trascendental:

No pertenecía al mundo real, pero tenía con él mucha relación. Penetraba en él muy hondamente; no obstante, cuanto más se hundía en la realidad, quedaba siempre fuera de ella.

Padecía de una exacerbatio cerebro, por lo que el mundo real no tenía para él suficientes estímulos (8).

En definitiva, la vida es, así para Augusto como para Johannes, un errar sumidos en una niebla cegadora, niebla que dificulta la existencia ${ }^{43}$.

La vida en la niebla sugiere la cuestión del ser. «¿Qué soy yo?» (140) se pregunta Augusto. Más adelante afirma convencido «yo soy yo» (211) y luego asegura a Eugenia: «eres tú que haces que yo no sea yo» (216). De otra parte, Domingo dice que «nadie es el que es, sino el que le hacen los demás» (221). Johannes expresa esa misma ansia por encontrar la identidad: «¿Qué soy yo?» $(106,107)$, pregunta en tres ocasiones a Cordelia, retóricamente, en una carta ${ }^{44}$.

${ }^{43}$ Estima, RoBerTs, Gemma, op. cit., 31. «resulta particularmente acertado el simbolismo de la niebla usado por Unamuno en su novela para describer el alma de su protagonista [...] Kierkegaard, en $O$ lo uno o lo otro, utiliza también la imagen de la niebla como expresión de una forma de existencia, la mística, que, junto con el esteticismo, propende a la negación de la realidad concreta y la historicidad de lo humano».

${ }^{44}$ ROBERTS, Gemma, op. cit., 36, señala similitudes entre el tratamiento de la existencia en Niebla y en la segunda parte de Enten-Eller, y certifica que «Unamuno hace referencia, al igual que Kierkegaard, a la sensación de plenitud provocada por la conciencia abstracta del yo en su validez eterna». 
La acción de Niebla oscila entre la realidad y la ficción, lo que culmina en la entrevista de Augusto con Unamuno. En el Diario del seductor se confunde también la realidad con la ficción: escribe el prologuista que, de conocerse la historia, Johannes «lo negaría todo, afirmando que el Diario no es más que una obra poética» (13) e incluso que Johannes «No pertenecía al mundo real, pero tenía con él mucha relación. Penetraba en él muy hondamente; no obstante, cuanto más se hundía en la realidad, quedaba siempre fuera de ella»(8).

A partir de las siete coincidencias apuntadas por Webber, esta crítica estima que «the two narratives diverge» ${ }^{45}$ : en Niebla la iniciativa seductora se transfiere de Augusto a Eugenia, quien lo abandona; en la novela de Kierkegaard, por el contrario, Cordelia es siempre la seducida, a quien al final abandona el seductor. Aparte de ese cambio, Webber atribuye las digresiones episódicas de Niebla al influjo del Diario del seductor, donde se contienen once episodios intercalados. Puesto que «The use of this device of novelistic interludes corresponds to the period in which Kierkegaard's influence upon Unamuno was strongest» ${ }^{46}$, conjetura Webber que los episodios intercalados de Niebla se deben a la influencia del Diario del seductor. Además de ello, Webber estima que la división del personaje de Augusto, en un «Augusto who existed in thought» en la primera parte y otro Augusto «who sought love» ${ }^{47}$ en la segunda parte, refleja un esquema parecido al del Diario del seductor. Ciertamente, ambas novelas coinciden en su carácter monologado, pero el uso de digresiones episódicas en Niebla no puede atribuirse a Kierkegaard. Entraña no poca dificultad localizar los once episodios intercalados que señala Webber. (Imagino que esta crítica se refiere a las historias de, por ejemplo, Hansen el teólogo o de Carlota Hahn). Las interpolaciones episódicas de Niebla poseen una extensión y una relación con la historia rectora que difieren en mucho del Diario del seductor; por el contrario, se corresponden con la definición que Edward Riley dio de las interpolaciones del Quijote: historias «de cierta extensión, con un mínimo de coherencia y cuyo origen y desarrollo, aunque no forzosamente su desenlace, carecen de relación con Don Quijote y Sancho» ${ }^{48}$, lo que no tienen en común con el Diario del seductor. Estos dos elementos, amén de la forma dialogada de Niebla, sirven a Webber para negar la influencia cervantina y proponer la kierkegaardiana. Como he apuntado (supra), tan arriesgada hipótesis ha podido propiciar que los críticos no hayan leído a Webber con la mucha atención que merece.

Concluye Webber su artículo presuponiendo que «It is possible that it

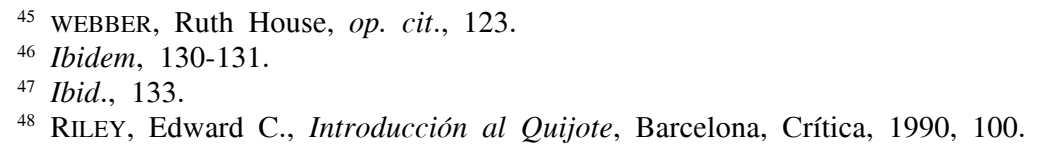


was Kierkegaard who suggested the basic idea of Niebla to Unamuno» ${ }^{49}$. Antes bien, las coincidencias entre Niebla y el Diario del seductor no se restringen a la concepción de la estructura narrativa y a la mera coincidencia de las situaciones que probó esta crítica. Como he demostrado en estas páginas, estos dos textos comparten mucho más, pues coinciden en su tenor tragicómico, en su concepción de la vida como niebla, en la reflexión y la divagación compulsivas de ambos protagonistas, en la psicología de los protagonistas y en la obsesión por el amor. Todo ello impide negar la influencia del Diario del seductor en Niebla, influencia capital para la redacción y la significación de la novela española. En esto, la ficción de Unamuno, de quien sabíamos que siguió a Kierkegaard en su obra filosófica, entronca, firme e impertérritamente, con la ficción del danés, y no con una obra cualquiera, sino con una de las novelas más emblemáticas de la literatura danesa. Las coincidencias que aquí he apuntado — las de Webber y las mías-, no pueden deberse al efecto del subconsciente. A Unamuno se le ha reprochado a veces que dependiese demasiado de otros autores, y hay incluso quien le ha motejado de plagiador ${ }^{50}$. Que omitiese el Diario del seductor en cuantos artículos escribió acerca de Niebla no sorprenderá a quien conozca bien la dependencia intertextual de muchas obras unamunianas. El Diario del seductor era un texto que carecía de traducción española, escrito por un autor de un país distante y compuesto en una lengua desconocida para la inmensa mayoría de los españoles. A Unamuno podía no interesarle reconocer la influencia de Kierkegaard, por no dar pie a críticas desmedidas; de callarla, lo normal era que nadie la advirtiese. De hecho, nadie hasta Webber reparó en ello.

\section{LAS INTERPERTACIONES DE NIEBLA}

La influencia incontestable de Kierkegaard en Niebla emplaza a una nueva consideración de esta novela. Las interpretaciones de Niebla proliferaron a lo largo de las décadas; no en vano las obras de Unamuno se han prestado a las más diversas exégesis, se han reinventado decenio tras decenio, con cada nueva marea de corrientes críticas. Todo ello ha cargado, ucrónicamente, de razón a Unamuno, quien insistió por activa y por pasiva en que toda obra literaria cobra vida propia y que solo a los lectores corresponde inter-

${ }^{49}$ WEBBER, Ruth House, op. cit., 132.

${ }^{50}$ V.g. RABATÉ, Jean-Claude, «Introducción», en Miguel de Unamuno, En torno al casticismo, Madrid, Cátedra, 2005, pp. 9-104, 28. En una carta a Clarín, citaba Unamuno de una reseña del primero: «No cita a nadie; todo lo dice como si aquellas novedades, que lo serán para muchos, se le hubieran ocurrido a él sólo, o como si no supiera él que ya han sostenido cosas parecidas otros. Pero no se crea que esto es por vanidad, por echarlas de erudito, etc.», citado en Manuel GARCía BLANCO, «Clarín y Unamuno», Archivium, 2,1952, pp. 113-135, 133. 
pretarla. Ello lo ha ilustrado perfectamente Carlos Blanco Aguinaga, quien, al estudiar San Manuel Bueno, mártir, se propuso acercarse «a un relato de Unamuno con la misma inocencia con que nos acercamos a otras obras de ficción: como si la obra que nos atrae fuese un complejo formal con existencia propia, independiente, hasta cierto punto, de su autor» ${ }^{51}$, que es como Unamuno creía que a todo lector corresponde acometer la lectura de una obra literaria. Así las cosas, no es mi intención, en el subsiguiente intento por poner en claro el meollo de Niebla, acomodar esta novela a mi horizonte de expectativas, propio, individual y subjetivo, sino desenmarañar la que, a la luz de Kierkegaard, creo que es la tesis principal de esta novela.

Las principales interpretaciones de Niebla han divagado en torno a cuestiones de índole literaria y filosófica. Eugenio de Nora ${ }^{52}$ creyó ver en $\mathrm{Au}$ gusto Pérez a una índole de personaje sin vida, al fantasma de la existencia. Para este crítico, la novela es horra, en términos ontológicos, de un protagonista e incluso de una trama que la vertebre; el único objeto de Unamuno al escribirla habría sido su afán por dirigirse a Dios. Por el contrario, Segundo Serrano Poncela ${ }^{53}$ concibe en Augusto a un verdadero personaje literario cuya existencia se restringe a sus propias inhabilidades sociales. Serrano concluye que el encuentro de Augusto con el mundo resulta absurdo, como absurda es la estructura del universo. Julián Marías ${ }^{54}$, por su parte, trató de aplicar un método filosófico en grado que entendiese Niebla como la respuesta al entendimiento de la dicotomía realidad-ficción. En su libro El Unamuno contemplativo, Carlos Blanco Aguinaga señaló que «Augusto Pérez había sido hijo único y éste es, seguramente, el origen de toda su tragedia: niño-hombre de regazo, empiezan sus tribulaciones al encontrarse solo en el mundo» ${ }^{55}$. En un trabajo posterior ${ }^{56}$, Blanco Aguinaga contempla la novela desde el desenlace y sugiere que el protagonista, en su decisión de cometer suicidio, se rebela ante los dictados del destino. En fechas muy recientes, yo mismo ${ }^{57}$ he apuntado la posibilidad de entender a Augusto como una suerte de trasunto de España, pues al igual que la España que vivió Unamuno, Augusto vaga solo por el mundo, a la deriva, sin rumbo aparentemente fijo.

51 Blanco Aguinaga, Carlos, «Sobre la complejidad de San Manuel Bueno, mártir, novela», en SÁNCHEZ-BARBUDO, Antonio (ed.), op. cit., pp. 273-296, 277.

52 NORA, Eugenio de, La novela española contemporánea, Madrid, Gredos, 1958, I, 23-25.

53 Serrano Poncela, Segundo, El pensamiento de Unamuno, Méjico, Fondo de Cultura Económica, 1953, pp. 186-187, 104-105.

${ }^{54}$ Marías, Julián, Miguel de Unamuno, Madrid, Espasa-Calpe, 1943, 7.

55 Blanco Aguinaga, Carlos, El Unamuno contemplativo, Méjico, El Colegio de Méjico, 1953, 129.

56 Idem., «Unamuno's Niebla: Existence and the Game of Fiction», Modern Language Notes, 89, 2, 1964, pp. 188-205.

57 ARDila, J.A.G., Etnografía y politología del 98: Unamuno, Ganivet y Maeztu, Madrid, Biblioteca Nueva, 2007, 14. 
El intento, quizá, más y mejor conocido por encontrar el sentido de Niebla se debe a Alexander Parker. Siguiendo a José Emilio González ${ }^{58}$, Parker propone que Orfeo, el perro de Augusto, es el personaje central del texto, y lo emparienta con una inveterada tradición literaria, iniciada por Cervantes y que llega hasta El amigo Manso de Galdós y el poema «Elegía en la muerte de un perro» de Unamuno. Concluye este crítico que «su tema central [de Niebla] es la tristeza de la condición humana que hace imposible la hermandad entre los hombres en la tierra, ya que la verdad y la inocencia no pueden coexistir en el amor con la pasión sexual» ${ }^{59}$.

Con mucho mayor tino, Ciriaco Morón Arroyo ha reparado en la complejidad de Niebla, obra que presenta como un río jalonado por remansos, alegoría en la cual la corriente fluvial es la trama, y los remansos, interludios de que precisa el lector a fin de meditar acerca de las implicaciones epistemológicas y teológicas de lo que lee. Distingue Morón Arroyo en Niebla varias «historias» ${ }^{60}$ que en conjunto cimientan la obra: 1) una historia ontológica, 2) historias de amores, 3) las historias de algunos personajes secundarios, v.g. don Fermín y el anarquismo, 4) la historia de don Avito Carrascal el irracionalista, 5) la de Víctor Goti y su atormentada parternidad, y 6) la de Antolín Paparrigópulos, que personifica la timidez intelectual. Las seis historias de Niebla toman cuerpo como, en palabras de Morón Arroyo, un conglomerado de «estudios sobre la inconsistencia humana» ${ }^{61}$. Y esta novela data, a creer de este crítico, el punto de inflexión de la obra unamuniana, pues a partir de su redacción, el autor se centró en una literatura de corte ontológico. Y finaliza su estudio Morón Arroyo: «Niebla trata el problema más radical de la persona humana: ser o no ser» ${ }^{62}$, todo lo cual se presenta conforme a los elementos de la filosofía clásica que antecede al existencialismo, a saber: esencia, existencia y hombre. Merced a esta minuciosa y concienzuda exégesis Morón Arroyo presenta Niebla como una obra, mutatis mutandi, imperfecta, en la cual los seis propósitos se funden y condensan sin destacarse ninguno de ellos en particular y ahogándose la diégesis en tanta digresión. Antes bien, sin objetar la presencia de las seis historias, cierto es asimismo que el carácter ontológico de esta novela cobra mayor relevancia en unas que en otras. En esas seis historias se distinguen tres

58 GonZÁlez, José Emilio, «Reflexiones sobre Niebla de Unamuno», Asomante, 17, 1961, 68.

59 PARKER, Alexander A., «En torno a la interpretación de Niebla», en SÁNCHEZ-BARBUDO, Antonio (ed.), op. cit., pp. 203-225, 224.

${ }^{60}$ Morón ARroyo, Ciriaco, «Niebla en la evolución temática de Unamuno», en $\mathrm{Ha}$ cia el sistema de Unamuno. Estudios sobre su pensamiento y creación literaria, Palencia, Cálamo, 2003, 69-86, 73, ensayo éste publicado antes, con el mismo título, en Modern Language Notes, 81, 1966, pp. 143-158.

61 Ibídem, 79.

62 Ibídem, 85. 
categorías: la historia ontológica de Augusto, que es historia rectora; las historias de amores, que se prodigan por la historia rectora, y las digresiones episódicas, que aparecen apenas en una ocasión, i.e. don Fermín, Avito Carrascal, Víctor Goti y Antolín Paparrigópulos, y que no forman parte de la historia rectora. Es decir, ampliando las conclusines de Morón Arroyo, que es menester tener el anarquismo (o la política en general), el irracionalismo, la paternidad y la timidez intelectual como temáticas secundarias que complementan la temática principal de Niebla, que es la preocupación ontológica por el amor. La historia ontológica presenta a Augusto en su paso por el mundo, el cual trata de entender. Como señala Morón, «Augusto se enamora de Eugenia, que es la nueva meta clara» ${ }^{63}$, meta que se yergue como objeto y término de la existencia del protagonista así como en meollo ontológico de la obra. El amor, pues, concentra la historia rectora, que se acompaña de las otras historias de amores, las cuales redundan en lo mismo. Observa Morón Arroyo que estos estudios filográficos contenidos en Niebla «se pueden reducir a cinco [aspectos]: la dificultad de amar, patología del amor, impurezas del amor, amor y espíritu y amor y ley» ${ }^{64}$. Del análisis de Morón Arroyo se colige que todo en Niebla, pues, gravita en torno a una misma temática: el amor como principio ontológico ${ }^{65}$.

Muchas y muy variadas han sido, en definitiva, las lecturas de Niebla. Pero la mayoría hemos parecido desviarnos o nos hemos mostrado remisos, en mayor o menor medida, a considerar lo que reconocemos como una verdad irrefutable: que Unamuno pensaba y escribía las más de sus obras de ficción conforme a las teorías, los impulsos y los pensamientos que rebullen en su producción de tenor pura y exclusivamente filosófico ${ }^{66}$. Se ha entendido a Augusto como un ente de ficción ${ }^{67}$ y los exegetas de Niebla han privilegiado la ficción sobre el ente, pues, no en vano, esta es una obra de ficción. No hace mucho, empero, Antonio López Molina ha recordado que, en Niebla, Unamuno «expone en forma de novela las grandes líneas argumentales de su ensayo filosófico más importante (Sentimiento trágico de la vida)» ${ }^{68}$ y Javier Herrero ha repara-

${ }^{63}$ Ibídem, 74.

64 Ibídem, 75.

65 Esto mismo opina de Amor y pedagogía HERRERO, Javier, «Imaginación erótica en Amor y pedagogía: la planta del hogar», Bulletin of Spanish Studies, 77, 2, 2000, pp. 41-55. Señala Herrero que «Unamuno quiere completar en Niebla las ideas sugeridas en la conclusión de Amor y pedagogía» (54). Recuérdese que Amor y pedagogía se ha reconocido como el antecedente novelesco de Niebla, v.g. en GARCÍA BLANCO, Manuel, «Amor y pedagogía, nivola unamuniana», La Torre, 9, 35-36, 1961, pp. 443-478; RIBBANS, Geoffrey, op. cit.

66 VAUTHIER, Bénédicte, en Arte de escribir e ironía en la obra narrativa de Miguel de Unamuno, Salamanca, Ediciones Universidad de Salamanca, 2004, ha argüido que la narrativa de Unamuno no se ha analizado suficientemente en diversos aspectos.

${ }^{67}$ Cf. PARKer, Alexander A., op. cit.

${ }^{68}$ LÓPEZ MolinA, Antonio, «Introducción», en Miguel de Unamuno, Del sentimiento trágico de la vida, Madrid, Biblioteca Nueva, 1999, 13-53, 18. También JoHnson, Roberta, 
do en que «El amor que vence en Niebla» es el mismo «amor puro» ${ }^{69}$ de que trata el capítulo VII de Del sentimiento. En efecto, las dos influencias más poderosas en Niebla emanan del Diario del seductor de Kierkegaard y Del sentimiento trágico de la vida. En los párrafos precedentes he cifrado el influjo del Diario. Acerca de Del sentimiento es hacedero tener en cuenta que se publicó en 1913, un año antes de que la edición prínceps de Niebla saliese de las prensas de la Editorial Renacimiento. Niebla, no obstante, quizá se comenzase en 1907 y Unamuno pudiera haberla concebido algo después de 1900. De uno u otro modo, la concepción y redacción de Niebla coincide en su época con Del sentimiento, o, cuando menos, se le acerca en mucho. En lo que sigue, explicaré cuál es la solución al sentido trágico de la vida para Kierkegaard en el Diario del seductor, cuál para Unamuno en Del sentimiento, para después procurar eso mismo en Niebla. De esta suerte, concluiré que en Niebla se presenta el amor como el verdadero sentido de la existencia.

\section{EL AMOR EN EL DIARIO DEL SEDUCTOR}

Las experiencias vitales de Kierkegaard ${ }^{70}$ iluminan la lectura crítica del Diario del seductor. En 1840, Kierkegaard, tras licenciarse en teología, se comprometió en matrimonio con la hermosa Regine Olsen. Dos meses más tarde, Søren rompió el compromiso, convencido de que Regine era una tentación que le distraería de su vocación de teólogo. En 1841 redactó las obras Frygt og Baven (traducida como Temor y temblor) y Gjentagelsen (traducida como Repetición) en que reflexionaba melancólicamente acerca de sus experiencias con Regine. En 1844 se publicó el Diario del seductor. La fuerza de la filosofía de Kierkegaard se genera, en líneas generales, desde un vitalismo angustiado. Para este pensador, la religión esconde la única respuesta válida para entender la vida. Al abandonar a Regine, Kierkegaard pretendía dedicarse a la religión por creer que sólo la religión podía asistirle en su entendimiento de la vida misma. En 1847, si embargo, plasma en un diario (que se publicaría póstumamente) la gran congoja que le produjo la boda de Regine con otro. En el Diario del seductor palpita desbocada la preocupación de Kierkegaard por el sentido de la vida: ¿qué es el amor?, ¿qué lugar corresponde al amor? y, sobre todo, ¿adónde conduce el amor? Para el protagonista y narrador, el amor es, en parte, una experiencia estética, el goce sublime que de la vida pueda extraerse.

op. cit., 93: «Niebla's composition is intrinsecably interwined with that of Del sentimiento trágico de la vida».

${ }^{69}$ Herrero, Javier, op. cit., 53.

${ }^{70}$ Sobre la vida de Kierkegaard vide: Pierre MESNARD, Kierkegaard: su vida, su obra, su pensamiento, Méjico, Universidad Nacional Autónoma de Méjico, 1966; Jolivet, R., Introducción a Kierkegaard, Buenos Aires, Nova, 1960. 
En la obra Om min Forfattervirksomhed (traducida como Mi punto de vista), de 1847, Kierkegaard explica su vida y su obra como un tránsito a través de tres avatares: uno estético, otro ético y un último religioso ${ }^{71}$. El amor por Regine pertenece al primer estadio, al estético. Aunque las experiencias de Johannes poseen un objeto estético (cf. supra), el Diario del seductor está redactado en la etapa religiosa de Kierkegaard. Por medio de la ficción, retorna de la religión al amor, para cuestionarse si no es el amor la verdadera respuesta a la existencia. En Mi punto de vista afirma: «No es la verdad la que gobierna el mundo, sino las ilusiones» ${ }^{72}$, y Johannes vive de ilusiones, de la ilusión de solazarse y realizarse, por medio del amor, en todas las mujeres — que es lo mismo que no gozarlo en ninguna-. Pero esas ilusiones, afirma Kierkegaard, gobiernan el mundo. Como Kierkegaard de Regine, Johannes se sabe enamorado sincera y profundamente de Cordelia (cf. supra). Del mismo modo que el autor en la vida real, el personaje novelesco renuncia al elskov o amor carnal, quizá porque, según escribe, le resulta imposible «seguir viviendo en eterna lucha conmigo mismo» (102). Pero el verdadero amor, el kjerlighed, es, como se lee en diversos puntos del Diario de Johannes, la sublimación espiritual, que no meramente carnal, a que puede aspirarse, porque solo el amor encierra la máxima pureza espiritual - como medita el narrador: «mi ideal fue siempre Diana. Siempre llenaron mi espíritu aquella pura virginidad, aquella total esquivez» (132) Por ello, asegura Johannes que «sé que el mayor deleite que se puede imaginar amando es el de ser amado, el de ser amado por encima de todas las cosas del mundo» (71).

Pero mucho más allá de la apariencia terrenal que el amor de Johannes pueda tener, el amor posee la capacidad de trascender la existencia terrena, que es la cuestión primera en gran parte de la obra de Kierkegaard. Johannes escribe en una misiva a Cordelia: «¿Qué soy yo? La gravedad terrestre que te encadena al suelo, a la tierra. ¿Qué soy yo? Materia, tierra, polvo y ceniza... y tú, mi Cordelia, eres espíritu y alma...» (107). Materia, tierra, polvo y ceniza son imágenes que, en la tradición cristiana, evocan la muerte. La muerte marca el final del camino vital de Johannes, quien sólo halla la

${ }^{71}$ La tesis fundamental del trabajo de Roberts se reduce a distinguir en Augusto estas tres etapas, que Roberts localiza en la segunda parte de Enten-Eller. ROBERTS, op. cit., 68, sigue a Morón Arroyo, de quien cita: «La historia ontológica se estructura conforme a la gradación paseante, caminante, viviente», y escribe la crítica estadounidense: Dichas gradaciones pueden relacionarse con los tres estadios de la dialéctica kierkegaardiana [...] De esta manera, vemos que el estadio estético se corresponde con la condición de paseante de Augusto Pérez; el ético equivale a su adquirida situación de caminante, cuando el personaje descubre un objetivo en su vida y tiene que responsabilizarse con la existencia; el estadio religioso se corresponde con su fase de sujeto viviente (yo preferiría el término «existente»), condición que implica la consideración de su ser finito y su relación con la eternidad; en suma, el angustioso problema de la dependencia de criatura y Creador.

${ }^{72}$ KierkegaARD, Søren, Mi punto de vista, Madrid, Sarpe, 1985, 77. 
inmortalidad en el amor verdadero que Cordelia le inspira, pues, por ser espíritu y alma, Cordelia simboliza la inmortalidad. Que ulteriormente la abandone se debe a tres razones: 1) a que la filosofía kierkegaardiana aboca siempre e irremisiblemente a la angustia, 2) a que el ideal filográfico de Johaness es platónico y 3) a que el mismo Kierkegaard abandonó a Regine. (Podría afirmarse que en esta obra el protagonista procede del mismo modo que procedió Kierkegaard con Regine: abandonándola. Como en la vida real, esa renuncia al amor supone un grave error). Johannes diferencia entre un amor espiritual o kjerlighed y un amor carnal o elskov: «Hay una diferencia entre erótica espiritual y terrenal» (116), escribe. El amor que él persigue, al menos en el caso de Cordelia, «Es una comprensión exclusivamente espiritual» (59). En virtud de todo ello, es menester leer en el Diario del seductor un canto al amor como único vehículo verdadero para trascender la muerte.

\section{EL AMOR EN DEL SENTIMIENTO TRÁGICO DE LA VIDA}

Críticos como Johnson, Sánchez-Barbudo, Mesnard y Ricard (supra) han apuntado la influencia de Kierkegaard en Del sentimiento trágico de la vida, que es la composición cardinal del pensamiento filosófico de Unamuno. Aun cuando Del sentimiento presenta toda suerte de complejidades, en esta obra se explana una idea axial del pensamiento de su autor: la búsqueda y el entendimiento de la inmortalidad ${ }^{73}$. La conclusión (que, quizá, no la solución) a este problema se esboza en el capítulo VI, titulado «En el fondo del abismo», donde se propone:

$\mathrm{Ni}$, pues, el anhelo vital de inmortalidad humana halla confirmación racional, ni tampoco la razón nos da aliciente y consuelo de vida y verdadera finalidad a ésta. Mas he aquí que en el fondo del abismo se encuentran la desesperación sentimental y volitiva y el escepticismo racional frente a frente, y se abrazan como hermanos. Y va a ser de este abrazo, un abrazo trágico, es decir, entrañadamente amoroso, de donde va a brotar manantial de vida, de una vida seria y terrible. El escepticismo, la incertidumbre, última posición a que llega la razón ejerciendo su análisis sobre sí misma, sobre su propia validez, es el fundamento sobre que la desesperación del sentimiento vital ha de fundar su esperanza $(95)^{74}$.

${ }^{73}$ Cf. Malvado De Miguel, E., Unamuno a la búsqueda de la Inmortalidad, Salamanca, San Pío X, 1977; vide asimismo: MeYer, François, La ontología de Miguel de Unamuno, Madrid, Gredos, 1962; Rivera DE Ventosa, E., Unamuno y Dios, Madrid, Encuentro, 1985; ÁlvAREZ GómEZ, Mariano, Unamuno y Ortega, La búsqueda azarosa de la verdad, Madrid, Biblioteca Nueva, 2004; Cerezo Galán, Pedro, op. cit.; CSEJTEI, Dezsö, Muerte e inmortalidad en la obra filosófica y literaria de Miguel de Unamuno, Salamanca, Ediciones Universidad de Salamanca, 2004; GonZÁlez CAMINERO, Nemesio, Unamuno: trayectoria de su ideología y de su crisis religiosa, Santander, Universidad Pontificia de Comillas, 1948.

${ }^{74}$ En lo sucesivo, todas las referencias a Del sentimiento trágico de la vida procederán de la edición de Biblioteca Nueva (Madrid, 1999). 
En ese mismo fondo insondable, Unamuno apunta tres apotegmas: 1) que la inmortalidad no acepta exégesis racionales, 2) que la vida brota de la desesperación sentimental y del escepticismo y 3) que la esperanza se halla en ese «escepticismo racional». De estas premisas se sigue como corolario que la vida es sentimiento y que la esperanza de inmortalidad se sustenta en el escepticismo racional. Esto es, que la vida debiera vivirse, a creer de Unamuno, con el corazón entregado al irracional sentimiento y con una mente escéptica a la vez que racional. La muerte puede conmensurarse con irrefutabilidad racional (se está muerto o no se está muerto), mas no así el sentimiento amoroso, por cuanto es irracional. La muerte es una certeza; el amor, un posible que gravita imbuido en mil circunstancias más o menos adversas. Se produce de esta suerte la lucha entre razón e intuición que tanto caracteriza el pensamiento unamuniano ${ }^{75}$ y que también confiesa Johannes en el Diario del seductor: «¿Cómo puedo seguir viviendo en eterna lucha conmigo mismo?»(102).

La tensión vital entre razón e intuición se constata en numerosos pasajes de Del sentimiento, en especial a lo largo del capítulo VII, «Amor, dolor, compasión y personalidad — que sigue al capítulo «En el fondo del abismo»- Mas a lo largo de esta obra, Unamuno establece dos verdades categóricas: 1) que, frente al amor carnal, existe un amor sentimental y 2) que este amor sentimental es trágico. La importancia del hondo sentir asoma desde los primeros párrafos de esta obra. Comienza Del sentimiento precisando que la humanidad es lo que es el hombre, «El hombre de carne y hueso, el que nace, sufre y muere — sobre todo muere-»(79), a lo que añade y matiza inmediatamente después que la filosofía no debiera denominar al hombre «animal racional», toda vez que el hombre es «un animal afectivo o sentimental» y «lo que de los demás animales le diferencia sea más el sentimiento que no la razón» (80). Esta capacidad de exacerbar el sentimiento se constata en la facultad de amar, a que Unamuno dedica una serie de pensamientos esenciales para su tesis.

Por amor significa Unamuno el amor sentimental. Aunque pudiera parecer que al escribir amor pretenda connotar un género de amor de carácter filantrópico o religioso, este amor es sentimental, puesto que Unamuno distingue claramente el amor espiritual o sentimental del amor carnal: divaga Unamuno acerca del «invencible instinto que empuja a un macho y una hembra», de «un amor carnal y primitivo» (166). Y del amor sentimental o espiritual opina: «Esta otra forma de amor, este amor espiritual, nace del dolor, nace de la muerte del amor carnal» (166). Esta idea es aplicable al Diario del seductor de Kierkegaard, en el cual la muerte del amor carnal engendra el verdadero amor espiritual de Cordelia (que ella declara con sublime franqueza en las cartas que confía al prologuista) y cabe suponer que de Johannes. Pero también establece Kierke-

${ }^{75}$ A que CSEJTEI, Dezsö, op. cit., 29, se ha referido como «la insolubilidad abierta». 
gaard en su novela esa misma distinción: «Hay una gran diferencia entre erótica espiritual y terrenal» (116).

Así las cosas, la coincidencia filográfica más relevante entre el Diario del seductor y Del sentimiento estriba en la relevancia que el amor tiene para la vida y para el entendimiento de la muerte: el amor es, así para Kierkegaard (cf. supra) como para Unamuno, la única vía posible para trascender la muerte. Ello lo expresa meridianamente el filósofo español en dos pasajes cardinales de Del sentimiento. El primero de estos pasajes se halla en el capítulo III:

De no serlo todo y por siempre, es como si no fuera, y por lo menos ser todo yo, y serlo para siempre jamás. $\mathrm{Y}$ ser yo es ser todos los demás. ¡O todo o nada!

¡O todo o nada! [...] ¡Eternidad!, ¡eternidad! Éste es el anhelo; la sed de eternidad es lo que se llama amor entre los hombres; y quien a uno ama es que quiere eternizarse en él. Lo que no es eterno tampoco es real (103-104).

Se lee aquí la relación entre ser y eternidad: se es sola y necesariamente si se es eternamente. «O todo o nada» (que evoca el título Enten-Eller de Kierkegaard) establece una oposición de contrarios, tan evidentes y ciertos como la vida terrenal y la muerte. Frente a esta contraposición de realidades racionales, Unamuno superpone el irracionalismo del sentimiento, del amar. En conclusión, estima que se ama porque se desea alcanzar, por medio de ese amor, la eternidad. Toda vez que el amor es la solución al problema de la eternidad, que inspira el sentimiento trágico de la vida, sólo el amor confiere significado y valor a la existencia terrena. Esto lo aclara Unamuno en el segundo pasaje a que me refería: «Es el amor [...] lo más trágico que en el mundo y en la vida hay; es el amor hijo del engaño y padre del desengaño, es el amor el consuelo en el desconsuelo, es la única medicina contra la muerte, siendo como es de ella hermana» $(165)^{76}$. Aunque dispares, las experiencias vitales de Kierkegaard y Unamuno confirman la creencia de ambos de que el amor, en palabras del español, «es la única medicina contra la muerte» (supra): en los remordimientos de Kierkegaard por haber abandonado a Regine - que se patentizan tras la boda de ella y, ulteriormente, cuando con su marido abandona Dinamarca y se instala en las Antillas-; en el amor profundo y fiel que Unamuno siempre demostró a su esposa ${ }^{77}$. Esta disparidad no se vale para desparejar Niebla y el Diario

${ }^{76}$ Cf. Herrero, Javier, op. cit., 55: «La penumbra vence a las llamas de Eros; aparentemente la muerte y el dolor vencen a la vida. Pero en esa penumbra brilla la luz [...] que anuncia la esperanza de esa vida eterna por la que Unamuno luchó hasta su muerte».

77 Apunta CARPIO, Adolfo P., op. cit., 125, que «Como Kierkegaard, Unamuno filosofa partiendo de su propia existencia personal, es decir, de los problemas que lo inquietan personalmente». El tratamiento más reciente en torno al matrimonio de Unamuno hállase en SANDOval, Antonio, «El concepto de mujer en el pensamiento de Unamuno», Cuadernos de la Cátedra Miguel de Unamuno, 39, 2004, pp. 27-60. 
del seductor. De hecho, la experiencia amorosa de Kierkegaard y Regine interesó y fascinó a Unamuno, quien la recrea en Una historia de amor, texto en el cual el Ricardo decide abandonar a su amada Liduvina porque:

Aquellos amores contrariaban su sino, bien manifiesto en señales de los cielos. Las palabras que el Evangelio le dijo aquella mañana cuando, después de haberse comulgado, lo abrió al azar de Dios, eran harto claras y no podían marrar. «Id y predicad la buena nueva por todas las naciones», Tenía que ser predicador del Evangelio, y para ello debía ordenarse sacerdote, y mejor aún, entrar en claustro de religión. Había nacido para apóstol de la palabra del Señor ${ }^{78}$.

Ricardo Gullón y David Turner ${ }^{79}$ han apuntado que este mismo impulso religioso acometió a Unamuno, aunque acabara casándose ${ }^{80}$.

\section{EL AMOR EN NIEBLA}

El Diario del seductor y Del sentimiento influyeron en Niebla de modo contundente. Al igual que Johannes, Augusto procura desesperadamente el sentimiento amoroso que sublime su existencia, y persigue ese sentimiento irracional por medio de sus reflexiones racionales. Y, como en el Diario del seductor y en Del sentimiento, en Niebla se plantea palmariamente la distinción entre amor carnal y amor sentimental o espiritual. Mario Valdés ha afirmado que el paraguas del capítulo I «representa la sexualidad y los problemas que Augusto tendrá con el encuentro sexual» ${ }^{81}$, esto es, que el fracaso de Augusto se debe a que no sabe conjugar el amor sentimental con el sexual. Muy por el contrario, Augusto, como Johannes y como se recomienda en Del sentimiento, no procura otra cosa que no sea el amor espiritual que dota la vida de un sentido hondo, lúcido y verdadero. Augusto representa el amor sentimental frente al amor carnal que promulga don Fermín (143), el amor económico por el que aboga doña Ermelinda (183185) y el amor pragmático y utilitarista de Eugenia por Mauricio, amores estos muy alejados de la espiritualidad trascendental del amor de Augusto. Eugenia orquesta el más vil de los engaños a fin de obtener lo material que

${ }^{78}$ UnAmuno, Miguel de, Una historia de amor, en San Manuel Bueno, mártir, y tres historias más, Madrid, Espasa-Calpe, 1987, 131.

${ }^{79}$ Gullón, Ricardo, Autobiografías de Unamuno, Madrid, Gredos, 1964; David G. Turner, Unamuno's Web of Fatality, Londres, Tamesis, 1974.

${ }^{80}$ Por su parte apunta Francisco La Rubia Prado, Unamuno y la vida como ficción, Madrid, Gredos, 1999: «Kierkegaard y Regine Olsen estuvieron, efectivamente, prometidos pero Kierkegaard rompió la relación con Regine, como hace Ricardo, para seguir a Dios. A la ruptura sigue un complejo proceso de racionalización de su decisión por parte de Kierkegaard. La mención del autor danés no ha de extrañar porque en su obra The Concept of Anxiety trata de cuestiones próximas al tema o temas de Una historia de amor, especialmente del pecado».

${ }^{81}$ VALDÉs, Mario J., op. cit., 26. 
le permita casarse con Mauricio, que no es más que un vividor. Esta oposición del amor espiritual a los amores carnales, económico y utilitarista se revela en los capítulos XV y XXVII. En el primero de estos promulga doña Ermelinda: «eso del amor es una cosa de libros, algo que se ha inventado no más que para hablar y escribir de ello. Tonterías de poetas. Lo positivo es el matrimonio. El código civil no habla del amor y sí del matrimonio. Todo eso del amor no es más que música...» (184). Eugenia detesta la música; sólo la utiliza para mantener su independencia económica y pagar la hipoteca. En el capítulo XXVII, cuando Augusto le pide que toque el piano, Eugenia repone «que desde que, gracias a tu generosidad, he podido ir dejando mis lecciones no he vuelto a tocar el piano y que lo aborrezco» (257). Inmediatamente después Augusto escribe un poema de amor y pide a Eugenia que lo enjuicie. Ella observa que esos versos son «Como mi piano, poco o nada musicales», que «Lo de 'dulce Eugenia' [en el poema] me parece un ripio» y que «Luego todo eso me parece muy... muy...» (256). Esto es, que Eugenia desprecia la música, que según su tía representa el amor sentimental, y los versos, que por ser «cosa de libros» (supra) son cosa del amor sentimental. O, en conclusión, que Eugenia desconoce y desprecia el amor espiritual y sentimental ${ }^{82}$.

De similar guisa que el galán danés (siquiera este no parezca saberlo en un principio, como quizá tampoco lo supiese Kierkegaard al cortejar a Regine), el español se esmera en seducir a quien ama sinceramente porque entiende que sólo el amor concede sentido a la vida y porque sólo el amor posee la facultad de trascender la muerte. En Niebla, la imposibilidad de realizarse mediante el amor verdadero quita todo sentido a la vida, y Augusto decide suicidarse ${ }^{83}$.

El suicidio constituye uno de los elementos temáticos capitales en Niebla. En realidad, no se especifica en momento alguno el porqué Augusto

${ }^{82}$ ROBERTS, Gemma, op. cit., 43-46, reflexiona en torno a la importancia de la música en la obra de Kierkegaard y el poco impacto que la música tuvo entre los literatos españoles de época de Unamuno. Estima Roberts que «En este sentido Kierkegaard, musical, y Unamuno, anti-musical, llegan a parecidas conclusiones en cuanto al repudio de la música, en la medida en que ambos se proyectan en una dimensión ético religiosa, ya sea la del temple contrarreformista del vasco [...] o la del puritanismo luterano del escritor danés» (44). Los argumentos de Roberts no me parecen especialmente aplicables a Niebla, donde el desdén de Eugenia y su tía por la música y las artes en general se yerguen como un muro que las separa de la concepción vital de Augusto. En ello se acentúa el esteticismo diletante del protagonista, su vivir marfileño; o también se incide en la superficialidad mundana de la dama y su familia.

${ }^{83}$ La cuestión del suicidio no está tan clara. Apunta Germán Gullón, op. cit., 20, que en los prólogos Víctor Goti y Unamuno «divergen con respecto a la causa de la muerte de Augusto Pérez, el protagonista de la obra; mientras el uno dice que Augusto se suicidó, el autor asegura que él decretó la muerte del personaje. En consecuencia, el lector tiene que decidir con qué versión quedarse, y, lo que es más importante, debe sopesar las implicaciones de ambas soluciones». 
decide poner fin a su vida. Tras descubrirse la añagaza de Eugenia, Augusto se pregunta «¿Qué es existir?»(275), y Víctor le responde: «¿Ves?, ya te vas curando: ya empiezas a devorarte. Lo prueba esa pregunta. iSer o no ser!..., que dijo Hamlet» (275). Esta es reflexión idéntica a la que se traza en Del sentimiento: « $\mathrm{O}$ todo o nada! ¡Y qué otro sentido puede tener el 'ser o no ser'! To be or not to be shakespeariano» (103). La existencia es todo o es nada. Con el amor lo es todo; sin el amor no es nada. Eso produce, como explica el narrador, «Aquella tempestad del alma de Augusto [que] terminó, como en terrible calma, en decisión de suicidarse» (277). Tras el fallecimiento del protagonista, su criada Liduvina, que lo conocía bien, certifica que se trata de un suicidio: «a mi señorito se le había metido en la cabeza morirse y, ¡claro!, el que se empeña en morir, al final muere» (293). El suicidio se debe, pues, a que, a falta del todo, a Augusto solo le queda la nada, esto es, una vida sin amor y, por consiguiente, sin la «medicina de la muerte» (supra) ${ }^{84}$.

Esto halla su justificación en el capítulo más importante para el entendimiento de la novela y de la psicología de Augusto. En el capítulo VII, Augusto monologa en presencia de Orfeo. Su discurso toca las siguientes cuestiones: el porqué del mundo, la cuestión de ser, la tragedia de la muerte y el amor. En este breve capítulo, Unamuno pasa de una cuestión a otra hasta proponer, como se explicita en Del sentimiento y en el Diario de un seductor, que el amor es la solución a la tragedia de la vida y de la muerte. «¿Qué necesidad hay de que haya ni Dios ni mundo ni nada?» (140) se pregunta Augusto antes de considerar «¿Qué soy yo?» (140). Explica después que a veces piensa «que yo no soy» (140), en lo que alude al vacío de su vida, a la nada. Augusto procede entonces a reflexionar en torno a la eternidad: «Cuando el hombre se queda a solas y cierra los ojos al porvenir, al ensueño, se le revela el abismo pavoroso de la eternidad. La eternidad no es porvenir» (141). Adviértase que el léxico coincide con el utilizado en Del sentimiento: eternidad y abismo. La muerte sugiere a Augusto un género de retroceso en la existencia ${ }^{85}$. Expuesto todo lo cual, el enamorado pasa de describir la nada en que se halla sumido, de explicar el temor a la muerte que interrumpe la eternidad, a detallar el todo:

Y ahora me brillan en el cielo de mi soledad los dos ojos de Eugenia. Me brillan con el resplandor de las lágrimas de mi madre. Y me hacen creer que existo, ¡dulce ilusión! Amo, ergo sum! Este amor, Orfeo, es como lluvia bienhechora en que se deshace y concreta la niebla de la existencia. Gracias al amor siento el alma de bulto, la toco. Empieza a dolerme en su cogollo mismo el alma,

\footnotetext{
${ }^{84} \mathrm{Ha}$ afirmado, RiBbANS, Geoffrey, op. cit., 131, que, para Augusto, «casarse quiere decir entrar de lleno en la vida». Ciertamente, al perder la posibilidad de desposar a quien ama, Augusto pierde la razón de su vida.

${ }^{85}$ ROBERTS, Gemma, op. cit., 33, lo compara al «proceso de disolución del yo» de Kiekergaard.
} 
gracias al amor, Orfeo. Y el alma misma, ¿qué es sino amor, sino dolor encarnado? (141).

De esta suerte, se expresa meridianamente que el amor confiere la existencia: Amo, ergo sum, esto es, que se es sola y exclusivamente si se ama. Y el amor deshace y concreta la niebla. En el amor está la solución a la ceguera producida por la niebla de la vida y a la vida misma. En el párrafo que sigue a esa cita descubre Augusto que solo el amor es eterno: «Vienen los días y pasan los días y el amor queda» (141). En esto ya repararon Donald Shaw, al apuntar que «The 'niebla de la existencia' ... clears away under love's influence» ${ }^{86}$, Anthony Close, para quien «In Niebla ... love is the root of all willed heroic action» ${ }^{87}$, Herrero, quien opina que el amor genera la esperanza de vida (citado supra), y, naturalmente, Morón Arroyo, quien entiende que «Eugenia es en Niebla lo que Dulcinea en la Vida de don Quijote y Sancho: el ideal que da sentido a la vida» ${ }^{88}$ y que, como se ha demostrado aquí, trasciende la muerte.

\section{CONCLUSIONES}

De todo lo aquí expuesto se colige lo siguiente. Primero, que Niebla recrea el Diario del seductor de Kierkegaard en aspectos sin número ${ }^{89}$ pero, sobre todo, en que Augusto pretende, como Johannes, alcanzar por medio del razonamiento el valor más absoluto de la existencia, que es lo que ambos autores denominan amor sentimental o espiritual. Segundo, que, tanto para Kierkegaard en el Diario del seductor como para Unamuno en Del sentimiento y en Niebla, el amor es lo único que puede trascender la muerte, esto es, que el amor es el todo y el desamor (o la ausencia del sentimiento amoroso) es la nada. Así da respuesta y solución Unamuno, en idénticos términos que el escritor de Copenhague, a la condición de «ser para la muerte» ${ }^{90}$.

Por consiguiente, en Niebla desarrolla Unamuno la temática del sentimiento trágico de la vida, la cuestión de la muerte y la eternidad, y en Niebla le da respuesta: el amor espiritual confiere sentido a la existencia. La tesis de Niebla — mi interpretación, que creo acertada y fiel a la intención de Unamuno- es la exaltación del amor espiritual o kjerlighed como solución al

\footnotetext{
${ }^{86}$ SHAw, Donald L., The Generation of 1898 in Spain, Londres, Ernest Benn, 1975, 50.

${ }^{87}$ Close, Anthony, The Romantic Approach to Don Quixote, Cambridge, Cambridge University Press, 1977, 151.

88 Morón Aarroyo, Ciriaco, op. cit., 74.

${ }^{89}$ Hasta el punto de que estima Gemma Roberts, op. cit., 65, que «Niebla podría entonces considerarse - aguzando un poco la imaginación- como la novela que Kierkegaard nunca escribió, pero quizás le hubiese encantado escribir». Opinión esta matizable, puesto que Kierkegaard escribió el Diario del seductor, que es una novela análoga en su esencia con Niebla.

90 Como la denominó Gullón, Ricardo, op. cit., 86.
} 
sentimiento trágico de la vida ${ }^{91}$. Veinte años después, aproximadamente, de que apareciese Niebla, Unamuno volvería a tratar la cuestión de la eternidad y la muerte en San Manuel Bueno, mártir. En esta otra novela, se pretende paliar el sentimiento trágico de la vida por medio de la religión ${ }^{92}$. Puede percibirse en Unamuno una suerte de evolución muy similar a la que Kierkegaard explica en Mi punto de vista: Unamuno pasa —en su obra literaria y en lo concerniente al tratamiento de la eternidad- de lo estético en Niebla a lo religioso de San Manuel.

Germán Gullón ha presentado Niebla, con todo acierto, como «un clásico de la novela moderna europea, que figura con derecho propio al lado de las obras de Virginia Woolf o de Luigi Pirandello» ${ }^{93}$ y A. C. Longhurst como la primera novela modernista española ${ }^{94}$. Es Niebla una excelente novela, trágica a la vez que ingeniosamente cómica, escrita y estructurada magistralmente; cumple y urge reconocerla como una joya literaria, deuda de Forf $\phi$ rerens Dagbog — que es una de las obras capitales de su época y de la literatura escandinava-, pero, sobre todo, es menester tenerla como un texto receptor de las más hondas, penetrantes y trascendentales reflexiones filosóficas que impregnan Del sentimiento trágico de la vida. Niebla exalta y enaltece el amor espiritual o sentimental como el más elevado y supremo de cuantos sentimientos vitales puedan concebirse y experimentarse. Tanto es así que su calidad catártica la convierten en un ejemplo de, como ha explicado Jonathan Culler, «la literatura como un objeto estético capaz de hacernos 'mejores'», toda vez que Niebla constata la tesis de este crítico estadounidense en cuanto a que «El objeto estético carente de finalidad práctica nos despierta maneras de reflexión e identificación y con ello nos ayuda a convertirnos en 'sujeto liberal', me-

${ }^{91}$ Idéntica conclusión a la que llegaron Javier Herrero al estudiar Amor y pedagogía y también Sarah Wright al analizar El hermano Juan. Apunta WRIGHT, op. cit., 126: «What Unamuno appears to have grasped from Kierkegaard's text, is the close relationship between the aesthetic and the ethical deviser, and the important of the dialectic between these two for the emergente of religión. He finds elements of all these three of these spheres embodied in the figure of Don Juan ... Love in its many forms, to my mind, is the element that links all of these elements».

${ }^{92}$ Sin referirse a San Manuel Bueno, mártir, de Niebla afirma acertadamente, FRIEDMAN, Edward H , op. cit., 252: «it is love, not religión, that moves [Augusto's] soul».

93 Gullón, Germán, op. cit., 10.

94 Longhurst, Alex C., «Ruptures and Continuities: From Realism to Modernism», en Lough, Francis (ed.), Hacia la novela nueva. Essays on the Spanish Avant-Garde Novel, Berna, Peter Lang, 2000, pp. 19-42, 31: Unamuno on the other hand, despite Realist beginnings in his historical novel Paz en la Guerra (1897), had fully earned his Modernist credentials with the publication of Niebla in 1914 ... here we encounter, perhaps for the first time in Spanish fiction, some of the central preoccupations of modernist narrative: an acutely self-conscious text aware of itself in the making; a sustained discussion of artistic autonomy-that of the text, of the characters and of the author; a concern with the role of language in human affairs including literature; a preoccupation with self-identity, and the authenticity of one's perceived image. 
diante el ejercicio libre y desinteresado de la facultad imaginativa que combina el saber y el juicio en la proporción correcta» ${ }^{95}$.

\section{REFERENCIAS BIBLIOGRÁFICAS}

AlaZRAKI, Jaime, «Motivación e invención en Niebla de Unamuno», Romanic Review, 58 (1967), pp. 241-253.

ÁlvAREZ GÓMEZ, Mariano, Unamuno y Ortega. La búsqueda azarosa de la verdad, Madrid, Biblioteca Nueva, 2004.

ARANGUREN, José Luis, «Sobre el talante religioso de Miguel de Unamuno», Arbor, 11, 36, 1948, pp. 485-503.

ARDILA, J.A.G., «El 'hacer política' de Unamuno y el punto de vista platónico-kierkegaardiano», Bulletin Hispanique, 104, 2001, pp. 169-190.

-, Etnografía y politología del 98: Unamuno, Ganivet y Maeztu, Madrid, Biblioteca Nueva, 2007.

BACHelor, R. F., Unamuno Novelist. A European Perspective, Oxford, Dolphin, 1972.

Berkowitz, H. C., «Unamuno's Relations with Galdós», Hispanic Review, 8, 1940, pp. 321-338.

Blanco Aguinaga, Carlos, «Sobre la complejidad de San Manuel Bueno, mártir, novela», en Antonio Sánchez-Barbudo, ed., Miguel de Unamuno, Madrid, Taurus, 1990, pp. 273-296.

—, «Unamuno's Niebla: Existence and the Game of Fiction», Modern Language Notes, 89, 2, 1964, pp. 188-205.

—, El Unamuno contemplativo, Méjico, El Colegio de Méjico, 1953.

BRETZ, Mary Lee, Encounters Across Borders. The Changing Visions of Spanish Modernism, 1890-1930, Lewisburg, Bucknell University Press, 2001.

CARPIO, Adolfo P., «Unamuno, filósofo de la subjetividad», en Antonio Sánchez-Barbudo (ed.), Miguel de Unamuno, Madrid, Taurus, 1990, pp. 123-150.

Cerezo Galán, Pedro, Las máscaras de lo trágico. Filosofía y tragedia en Miguel de Unamuno, Madrid, Trotta, 1996.

Close, Anthony, The Romantic Approach to Don Quixote, Cambridge, Cambridge University Press, 1977.

Collado, Jesús Antonio, Kierkegaard y Unamuno. La existencia religiosa, Madrid, Gredos, 1962.

CSEJTEI, Dezsö, Muerte e inmortalidad en la obra filosófica y literaria de Miguel de Unamuno, Salamanca, Ediciones Universidad de Salamanca, 2004.

CULler, Jonathan, Breve introducción a la teoría literaria, Barcelona, Crítica, 2000.

FARRÉ, LUIS, «Unamuno, William James y Kierkegaard y otros ensayos, Buenos Aires, La Aurora, 1967.

FASEL, Oscar, «Observations on Unamuno and Kierkegaard», Hispania, 38, 1955, pp. 443450.

FranZ, Thomas R., «El sentido del humor y adquisición de autoconciencia en Niebla», Cuadernos de la Cátedra Miguel de Unamuno, 23, 1973, pp. 5-25.

FrIEDMAN, Edward H., Cervantes in the Middle. Realism and Reality in the Spanish Novel from Lazarillo de Tormes to Niebla, Newark, Juan de la Cuesta, 2006.

${ }^{95}$ CUlLeR, Jonathan, Breve introducción a la teoría literaria, Barcelona, Crítica, $2000,51$. 
Galán, Pedro Cerezo, Las máscaras de lo trágico. Filosofía y tragedia en Miguel de Unamuno, Madrid, Trotta, 1996.

GANivet, Ángel, Cartas Finlandesas y Hombres del Norte, Madrid, Espasa-Calpe, 1998.

GARCÍA BACCA, J.D., «Kierkegaard y la filosofía contemporánea española», Cuadernos Hispanoamericanos, 150-151, 2, 1967, pp. 94-105.

GarCía BlanCO, Manuel, «Clarín y Unamuno», Archivium, 2, 1952, pp. 113-135.

—, «Amor y pedagogía, nivola unamuniana», La Torre, 9, 35-36, 1961, pp. 443-478.

GILlET, Joseph E., «The Autonomous Character in Spanish and European Literature», Hispanic Review, 24, 1946, pp. 179-190.

GonZÁlez CAMINERo, Nemesio, Unamuno: trayectoria de su ideología y de su crisis religiosa, Santander, Universidad Pontificia de Comillas, 1948.

GonZÁleZ EgIDO, Luciano, «Introducción», en Miguel de Unamuno, En torno al casticismo, Madrid: Espasa-Calpe, 1998.

GonZÁlEZ, José Emilio, «Reflexiones sobre Niebla de Unamuno», Asomante, 17, 1961, 68.

GuLLÓN, Germán, «Introducción», en Miguel de Unamuno, Niebla. Madrid, Espasa-Calpe, 2006.

Gullón, Ricardo, Autobiografías de Unamuno, Madrid, Gredos, 1964.

HERRERO, Javier, «Imaginación erótica en Amor y pedagogía: la planta del hogar», Bulletin of Spanish Studies, 77, 2, 2000, pp. 41-55.

ILIE, Paul, Unamuno: An Existential View of Self and Society, Madison, University of Wisconsin Press, 1967.

Johnson, Roberta, Crossfire. Philosophy and the Novel in Spain, 1900-1934, Lexington, The University Press of Kentucky, 1993.

Jolivet, R., Introducción a Kierkegaard, Buenos Aires, Nova, 1960.

KIERKEgAard, Søren, Diario de un seductor (arte de amar), Madrid, Espasa-Calpe, 1968.

—, Diario de un seductor, León Ignacio (trad.), Barcelona, Ediciones 29, 1989.

—, Either/Or, David F. Swenson y Lillian M. Swenson (trads.), Nueva York, Anchor, 1959.

—, Il diario del seduttore, Luigi Redaelli (trad.), Torino, 1910.

—, Mi punto de vista, José Miguel Velloso (trad.), Madrid, Sarpe, 1985.

KING, W. F., «Unamuno, Cervantes y Niebla», Revista de Occidente, 16, 1967, pp. 219-231.

La Rubia PRAdo, Francisco, Unamuno y la vida como ficción, Madrid, Gredos, 1999.

LeboIs, A., «La révolte des personages: de Cervantes à Raymond Schwabi», Revue de Littérature Comparée, 23, 1949, pp. 248-295.

Livingstone, Leon, «Interior Duplication and the Problem of Form in the Modern Spanish Novel», PMLA, 73 (1958), pp. 393-406.

Longhurst, Alex C., «Ruptures and Continuities: From Realism to Modernism», en Francis Lough (ed.), Hacia la novela nueva. Essays on the Spanish Avant-Garde Novel, Berna, Peter Lang, 2000, 19-42.

LóPEZ Molina, Antonio, «Introducción», en Miguel de Unamuno, Del sentimiento trágico de la vida, Madrid, Biblioteca Nueva, 1999, 13-53.

Malvado De Miguel, E., Unamuno a la búsqueda de la Inmortalidad, Salamanca, San Pío X, 1977.

MARÍAS, Julián, Miguel de Unamuno, Madrid, Espasa-Calpe, 1943.

MESNARD, Pierre y PICARD, Robert, «Aspects noveaux d'Unamuno», La Vie Intellectuelle, 1946, pp. 112-138.

MeSnARD, Pierre, Kierkegaard: su vida, su obra, su pensamiento, Méjico, Universidad Nacional Autónoma de Méjico, 1966.

MEYER, François, «Kierkegaard and Unamuno», Revue de Littérature Comparée, 29, 1955, pp. $478-492$. 
—, La ontología de Miguel de Unamuno, Madrid, Gredos, 1962.

MORón Arroyo, Ciriaco, Hacia el sistema de Unamuno. Estudios sobre su pensamiento y creación literaria, Palencia, Cálamo, 2003.

NORA, Eugenio de, La novela española contemporánea, Madrid, Gredos, 1958.

Padilla NovoA, M., Unamuno (1864-1936), Madrid, Ediciones del Orto, 1994.

-, M., Unamuno, filósofo de encrucijada, Madrid, Cincel, 1985.

PALMER, Donald D., «Unamuno's Don Quijote and Kierkegaard's Abraham», Revista de Estudios Hispánicos, 3, 1969, pp. 295-312.

PARís, Carlos, Unamuno. Estructura de su mundo intelectual, Valencia, Península, 1968.

PARKER, Alexander A., «En torno a la interpretación de Niebla», en Antonio SánchezBarbudo (ed.), Miguel de Unamuno, Madrid, Taurus, 1990, pp. 203-225.

RABATÉ, Jean-Claude, «Introducción», en Miguel de Unamuno, En torno al casticismo, Madrid, Cátedra, 2005, pp. 9-104.

RiBBANS, Geoffrey, «La evolución de la novelística unamuniana: Amor y pedagogía y Niebla», en Niebla y Soledad: aspectos de Unamuno y Machado, Madrid, Gredos, 1971, pp. 83-107.

RiLEY, Edward C., Introducción al Quijote, Barcelona, Crítica, 1990.

Rivera DE Ventosa, E., Unamuno y Dios, Madrid, Encuentro, 1985.

ROBERTS, Gemma, Unamuno, afinidades y coincidencias kierkegaardianas, Boulder, Society of Spanish and Spanish-American Studies, 1986.

SÁNChez RuIZ, J. M., Razón, mito y tragedia: ensayo sobre la filosofía de Don Miguel de Unamuno, Zúrich, 1964.

SÁNCHEZ-BARBUDO, Antonio, «Una experiencia decisiva: la crisis de 1897», en Antonio Sánchez-Barbudo (ed.), Miguel de Unamuno, Madrid, Taurus, 1990, pp. 95-122.

SANDERS, Karin, «Blik og forførelse. Om Søren Kierkegaards Forførerens Dagbog», KRITIK, 86, 1988, pp. 54-63.

SANDOVAL, Antonio, «El concepto de mujer en el pensamiento de Unamuno», Cuadernos de la Cátedra Miguel de Unamuno, 39, 2004, pp. 27-60.

SERrano Poncela, Segundo, El pensamiento de Unamuno, Méjico, Fondo de Cultura Económica, 1953.

Shaw, Donald L., The Generation of 1898 in Spain, Londres, Ernest Benn, 1975.

SINCLAIR, Alison, «Concepts of Tragedy in Unamuno and Kierkegaard», en Nicholas G. Round (ed.), Re-reading Unamuno, Glasgow, University of Glasgow Press, 1989, pp. 121-138.

-, Alison, Uncovering the Mind. Unamuno, the Unknown and the Vicissitudes of Self, Manchester, Manchester University Press, 2001.

TURNer, David G., Unamuno's Web of Fatality, Londres, Tamesis, 1974.

Unamuno, Miguel de, Del sentimiento trágico de la vida, Madrid, Biblioteca Nueva, 1999.

—, Miguel de, Niebla, Madrid, Cátedra, 2005.

-, Miguel de, San Manuel Bueno, mártir, y tres historias más, Madrid, Espasa-Calpe, 1987.

USCATESCU, Jorge, «Unamuno y Kierkegaard o la interioridad secreta», Arbor, 103, 1979, pp. $25-40$.

VALDÉs, Mario J., An Unamuno Source Book, Toronto, University of Toronto Press, 1973.

—, Mario J., «Introducción», en Miguel de Unamuno, Niebla, Madrid, Cátedra, 2005, pp. $9-59$.

WALTHER, Bo Kampmann, «Sækulariseret apokalypse. Et essay om forvitret retorik og billedsprog i Søren Kierkegaards Forførerens Dagbog», Rhetorica Scandinavica, 2, pp. 36-53. 
WEBBER, Ruth House, «Kierkegaard and the Elaboration of Unamuno's Niebla», Hispanic Review, 32, 1964, pp. 118-134.

WRIGHT, Sarah, «Ethical Seductions: A Comparative Reading of Unamuno's El hermano Juan and Kierkegaard's Either/Or», Anales de la Literatura Española Contemporánea, 29, 2, 2004, pp. 119-134.

Fecha de recepción: 3 de marzo de 2007

Fecha de aceptación: 12 de febrero de 2008 